Prepared in cooperation with the Village of Endicott, New York

\title{
Hydrogeology of the Susquehanna River Valley-Fill Aquifer System in the Endicott-Vestal Area of Southwestern Broome County, New York
}

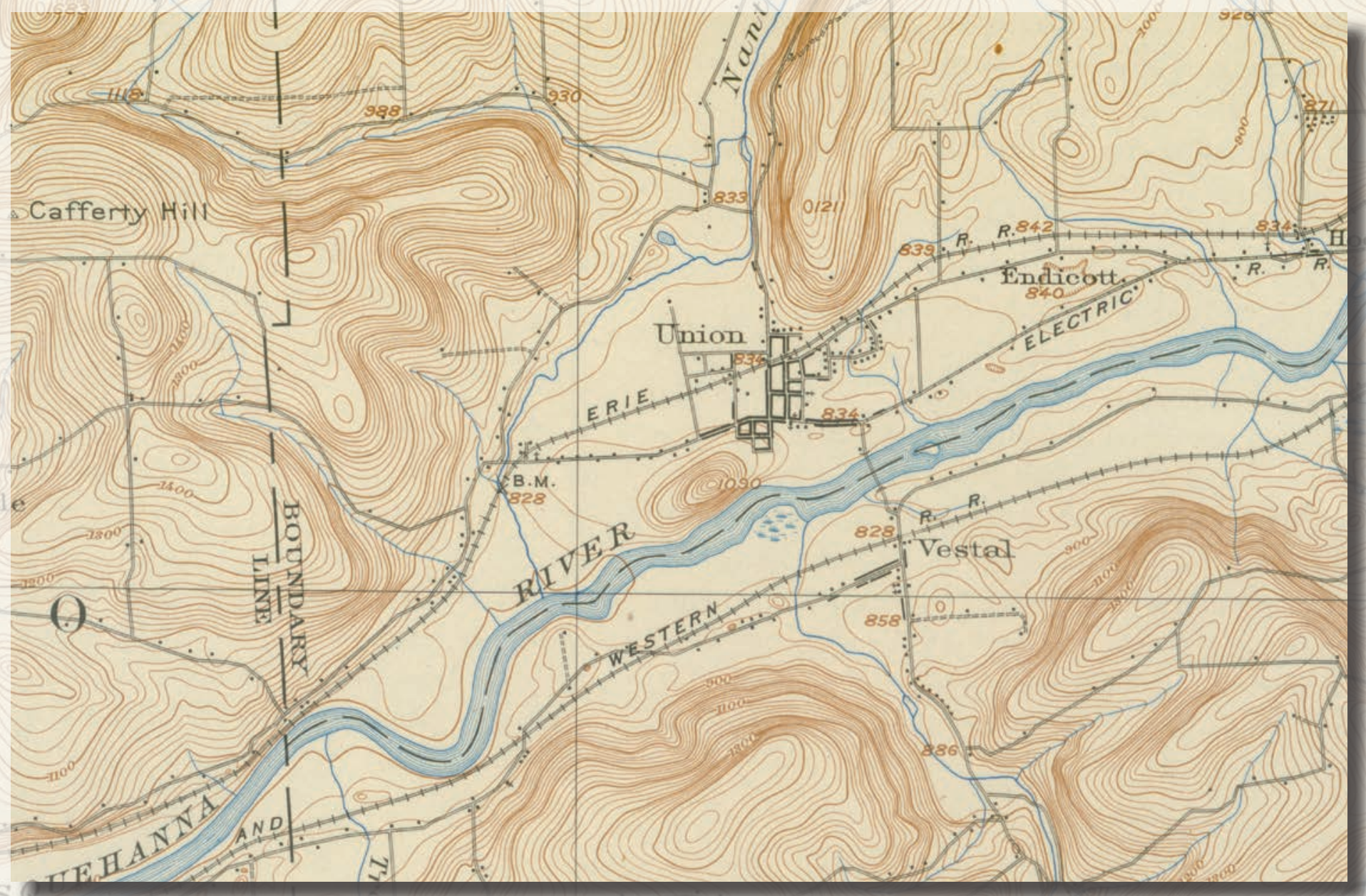

Scientific Investigations Report 2015-5078

U.S. Department of the Interior

U.S. Geological Survey 
Cover. Topographic map showing the southeastern corner of the Apalachin, New York, 15-minute quadrangle mapped in 1904. 


\section{Hydrogeology of the Susquehanna River Valley-Fill Aquifer System in the Endicott- Vestal Area of Southwestern Broome County, New York}

By Allan D. Randall and William M. Kappel

Prepared in cooperation with the Village of Endicott, New York

Scientific Investigations Report 2015-5078 


\title{
U.S. Department of the Interior SALLY JEWELL, Secretary
}

\section{U.S. Geological Survey \\ Suzette M. Kimball, Acting Director}

\author{
U.S. Geological Survey, Reston, Virginia: 2015
}

For more information on the USGS - the Federal source for science about the Earth, its natural and living resources, natural hazards, and the environment-visit http://www.usgs.gov/ or call 1-888-ASK-USGS.

For an overview of USGS information products, including maps, imagery, and publications, visit http://www.usgs.gov/pubprod/.

Any use of trade, firm, or product names is for descriptive purposes only and does not imply endorsement by the U.S. Government.

Although this information product, for the most part, is in the public domain, it also may contain copyrighted materials as noted in the text. Permission to reproduce copyrighted items must be secured from the copyright owner.

Suggested citation:

Randall, A.D., and Kappel, W.M., 2015, Hydrogeology of the Susquehanna River valley-fill aquifer system in the Endicott-Vestal area of southwestern Broome County, New York: U.S. Geological Survey Scientific Investigations Report 2015-5078, 28 p. plus appendixes, http://dx.doi.org/10.3133/sir20155078.

ISSN 2328-0328 (online) 


\section{Contents}

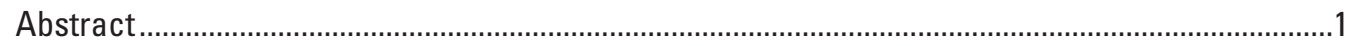

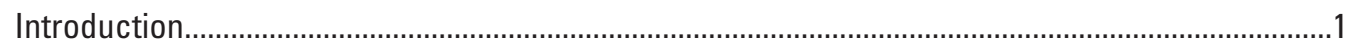

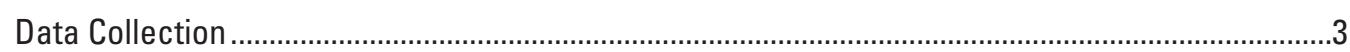

Well and Borehole Records ..............................................................................................

Test Boreholes Logged by U.S. Geological Survey Personnel..................................................

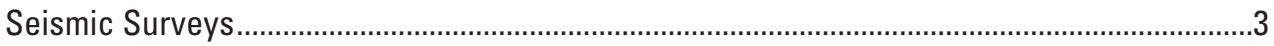

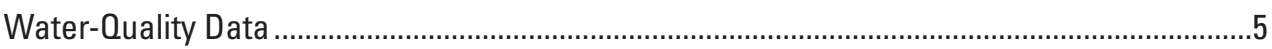

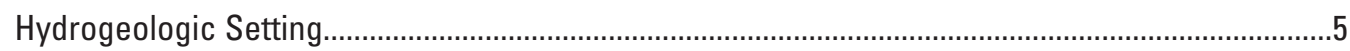

Aquifer Geometry in the Susquehanna River Valley-Fill Aquifer System .........................................7

Successive Episodes of Valley-Fill Sediment Deposition ............................................................

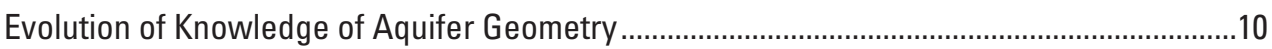

Delineation of Aquifer Geometry Within the Valley Fill ............................................................11

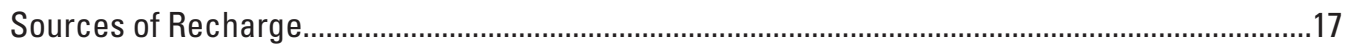

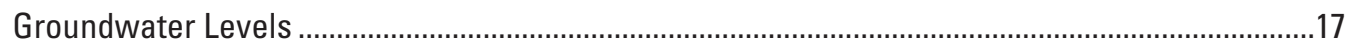

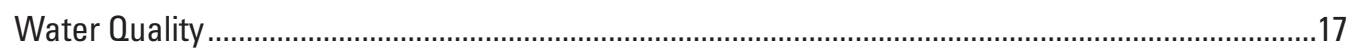

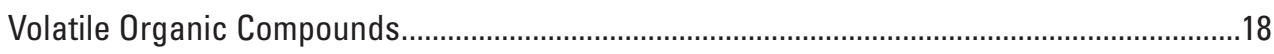

Prospects for Municipal Wells in Western Endicott............................................................19

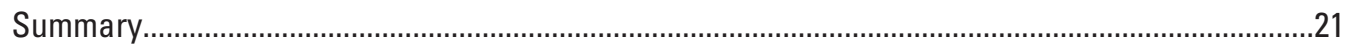

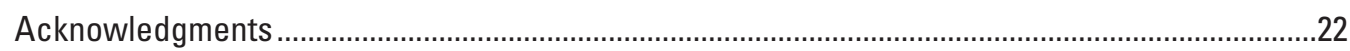

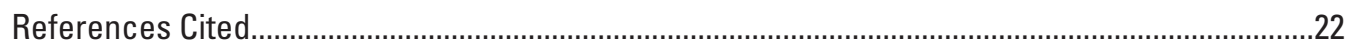

Appendix 1. Tabulated Records of Wells and Test Holes in the Susquehanna River Valley-Fill Aquifer System, Southwestern Broome County, New York..............................................27

Appendix 2. Map of Records of Wells and Test Holes in the Susquehanna River Valley-Fill Aquifer System, Southwestern Broome County, New York..............................................27

Appendix 3. Detailed Logs by U.S. Geological Survey Personnel of Sediments Penetrated by Test Holes in the Susquehanna River Valley Fill, Southwestern Broome County, New York

Appendix 4. Physical and Chemical Properties of Water Samples from the Susquehanna River Valley-Fill Aquifer System, and from the Susquehanna River Near Endicott, New York.

\section{Figures}

1. Map showing the Susquehanna River valley-fill aquifer system, location of production wells, and a U.S. Geological Survey streamgage in the Triple Cities (Binghamton, Johnson City, and Endicott) area of southwestern Broome County, New York

2. Map showing the locations of wells, water-quality data sites, passive seismic survey sites, lines of geologic section, and inactive landfills in the Susquehanna River valley-fill aquifer system, southwestern Broome County, New York.

3. Graph showing comparison of depth to bedrock estimated from horizontal-tovertical spectral ratio (HVSR) passive seismic surveys and depth to bedrock reported from nearby wells, the distance between each well/HVSR pair, and the geographic location of each pair in the Endicott area, Broome County, New York 
4. Map showing the bedrock-surface altitude inferred from passive seismic surveys and from wells that penetrate to or nearly to the bedrock surface in the

Susquehanna River valley, southwestern Broome County, New York

5. Map showing aquifer geometry in the Susquehanna River valley, near Endicott and Vestal, southwestern Broome County, New York.

6. Geologic sections in the Susquehanna River valley, near Endicott and Vestal, southwestern Broome County, New York

7. Map showing localities in which aquifers capable of providing large groundwater supplies are inferred to be present but are not tapped as of 2014, in the Susquehanna River and lower Nanticoke Creek valleys, western Endicott, Broome County, New York.

\section{Conversion Factors}

Inch/Pound to International System of Units

\begin{tabular}{lcl}
\hline \multicolumn{1}{c}{ Multiply } & By & \multicolumn{1}{c}{ To obtain } \\
\hline inch (in.) & Length & \\
foot (ft) & 25.4 & millimeter $(\mathrm{mm})$ \\
mile (mi) & 0.3048 & meter $(\mathrm{m})$ \\
\hline & 1.609 & kilometer $(\mathrm{km})$ \\
\hline square mile $\left(\mathrm{mi}^{2}\right)$ & Area & \\
\hline & 2.590 & square kilometer $\left(\mathrm{km}^{2}\right)$ \\
\hline gallon per minute $(\mathrm{gal} / \mathrm{min})$ & Flow rate & \\
\hline & 0.06309 & liter per second $(\mathrm{L} / \mathrm{s})$ \\
\hline picocurie per liter $(\mathrm{pCi} / \mathrm{L})$ & Radioactivity & \\
\hline
\end{tabular}

Temperature in degrees Celsius $\left({ }^{\circ} \mathrm{C}\right)$ may be converted to degrees Fahrenheit $\left({ }^{\circ} \mathrm{F}\right)$ as ${ }^{\circ} \mathrm{F}=\left(1.8 \times{ }^{\circ} \mathrm{C}\right)+32$.

\section{Datum}

Vertical coordinate information is referenced to the North American Vertical Datum of 1988 (NAVD 88).

Horizontal coordinate information is referenced to the North American Datum of 1983 (NAD 83). Altitude, as used in this report, refers to distance above the vertical datum. 


\title{
Supplemental Information
}

Specific conductance is given in microsiemens per centimeter at 25 degrees Celsius $(\mu \mathrm{S} / \mathrm{cm}$ at $\left.25^{\circ} \mathrm{C}\right)$.

Concentrations of chemical constituents in water are given in either milligrams per liter (mg/L) or micrograms per liter $(\mu \mathrm{g} / \mathrm{L})$.

\section{Abbreviations}

\author{
GWSI Groundwater Site Inventory \\ HVSR horizontal-to-vertical spectral ratio \\ KMZ keyhole markup language zipped \\ NWIS National Water Information System \\ N.Y. New York \\ USGS U.S. Geological Survey \\ VOC volatile organic compound
}





\title{
Hydrogeology of the Susquehanna River Valley-Fill Aquifer System in the Endicott-Vestal Area of Southwestern Broome County, New York
}

\author{
By Allan D. Randall and William M. Kappel
}

\section{Abstract}

The village of Endicott, New York, and the adjacent town of Vestal have historically used groundwater from the Susquehanna River valley-fill aquifer system for municipal water supply, but parts of some aquifers in this urban area suffer from legacy contamination from varied sources. Endicott would like to identify sites distant from known contamination where productive aquifers could supply municipal wells with water that would not require intensive treatment. The distribution or geometry of aquifers within the Susquehanna River valley fill in western Endicott and northwestern Vestal are delineated in this report largely on the basis of abundant borehole data that have been compiled in a table of well records.

Early in deglaciation, meltwater deposited sand and gravel in channels within or beneath the decaying ice and as narrow terraces along the valley walls. These ice-contact deposits vary widely over short distances from clean (free of silt) and highly permeable to clogged with silt and poorly permeable, but collectively constitute the principal aquifers in Endicott and Vestal. Some ice-contact deposits form a buried ridge, deposited in a meltwater channel within the ice sheet, that approximately underlies the Susquehanna River and (or) its north bank from Endwell westward to Nanticoke Creek and has been tapped by several municipal and industrial wells. Similar but thinner ice-contact deposits discontinuously underlie the valley floor to the south in Vestal, and a smaller buried ridge of ice-contact deposits is likely beneath or west of Nanticoke Creek south of West Corners.

As deglaciation continued, a large lake developed; thick deposits of gray silt with red clay layers are continuous north of the Susquehanna River from Endwell to West Endicott, and similar deposits are present discontinuously elsewhere. Late in deglaciation, meltwater deposited highly permeable pebbly sand atop the valley fill, generally atop lacustrine silt. The saturated thickness of this surficial sand is seldom great enough to support large-capacity wells, but where it directly overlies ice-contact deposits it facilitates recharge from precipitation and infiltration of river water to the deeper aquifers.
Three localities in Endicott were identified where thick ice-contact deposits capable of supporting municipal supply wells are documented by test wells or extrapolated to be present from nearby data and depositional history. Chemical analyses of water samples disclosed no contaminants in these localities when sampled, but the presence of contaminants or natural high iron a few thousand feet away from each locality is documented.

\section{Introduction}

Broome County, New York lies within the Appalachian Plateau, a region of substantial relief wherein the Susquehanna River follows a valley about a mile wide, the floor of which is more than 700 feet below hilltops in the bordering uplands. The village of Endicott occupies the valley floor north of the river in westernmost Broome County, about 7 miles west of Binghamton, N.Y. (fig. 1). The valley floor south of the river and the adjacent uplands in New York southward to the Pennsylvania border are part of the town of Vestal. The unconsolidated sediments beneath the valley floor are collectively referred to as the Susquehanna River valleyfill aquifer system, and include highly permeable sand and gravel aquifers of various origins, interbedded with silt, clay, silty gravels, and a basal till layer atop bedrock. Since about 1912, Endicott has obtained municipal water supply from wells that penetrate sand and gravel within the Susquehanna River valley fill. Since about 1981, an increasing number of the wells currently in use have yielded water containing small concentrations of volatile organic compounds (VOCs), which has required remedial water treatment and (or) pumping auxiliary wells to intercept contaminants. Therefore, the village would like to identify localities distant from known contamination where sand and gravel aquifers would be capable of sustaining large groundwater withdrawals. A recent study of the watershed of Nanticoke Creek, which enters the Susquehanna River valley from the north in western Endicott, concluded that the valley-fill sediments in that watershed are not capable of yielding the quantity of water needed to supply the village (Kreitinger and Kappel, 2014). 


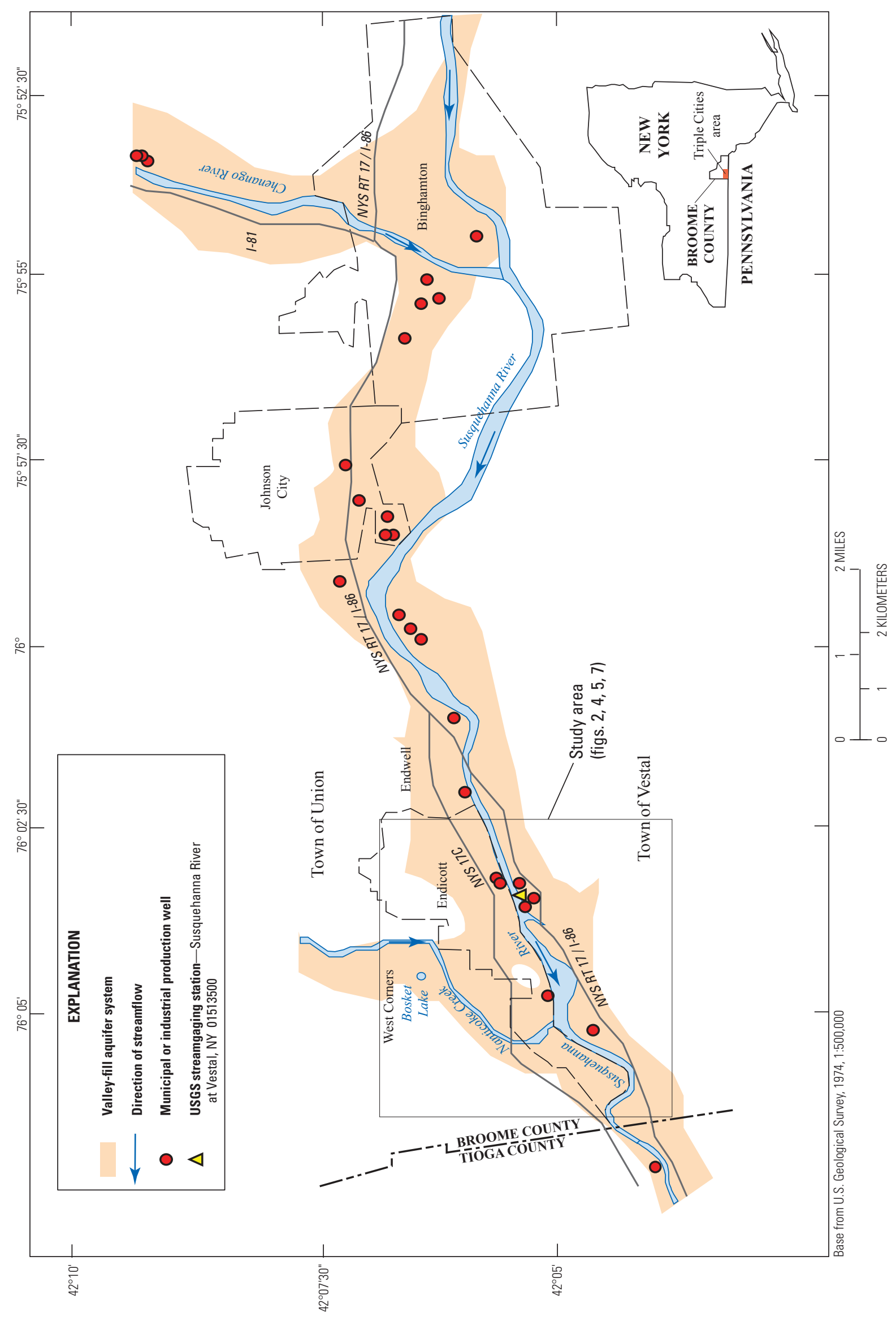

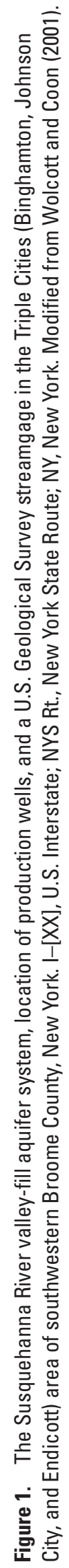


A study was undertaken by the U.S. Geological Survey (USGS) in cooperation with the village of Endicott to characterize the valley-fill aquifer system in this reach of the Susquehanna River valley. The current report is focused on the unconsolidated sediments beneath the floor of the Susquehanna River valley in western Endicott, which includes the downstream 2 miles of Nanticoke Creek, but also considers the adjacent valley fill in Vestal. The report evaluates the distribution or geometry of aquifers within the valley fill, on the basis of borehole data from past investigations by others for water supplies, highway construction, and remediation of water quality, as well as seismic surveys and borehole logging by the USGS as part of the current and previous studies. Patterns of sediment lithology and glacial history that can help evaluate aquifer continuity within the valley fill are briefly explained. The possible influence of legacy contamination on potentially productive aquifers is considered, based largely on water-quality information in reports cited herein; quantitative appraisal of migration of contaminants is beyond the scope of this report. All locality names (town, village, hamlet, and so forth) mentioned in this report are in Broome County, New York.

\section{Data Collection}

Several types of data were collected as part of this study from a variety of sources and from onsite measurements.

\section{Well and Borehole Records}

Records of wells and other boreholes in the Susquehanna River valley were collected from publications and formal reports, chiefly Randall (1972), Lozier/Ground Water Associates (1978), Martin and others (1983), Adams and Grant (1984), Grant (1985), Ecology and Environment (1986), Goldberg-Zoino Associates (1987), and Groundwater Sciences Corporation (2013), also from informal reports to the town of Vestal by consultants and well drillers. A few records were provided by property owners, well drillers, and the New York State Department of Transportation. Boreholes deemed important to the study have been assigned USGS identification numbers and entered into the USGS Groundwater Site Inventory (GWSI) database; these records are summarized in appendix 1 and the locations are plotted on figure 2 .

The record of each well in the study area can also be accessed through a keyhole markup language zipped (KMZ) map that is linked to a Google Earth image of the study area. When the symbol for any one well is selected or clicked on the map, a table of well information for that particular well will appear on the map. This KMZ map is designated as appendix 2 .

\section{Test Boreholes Logged by U.S. Geological Survey Personnel}

Five test boreholes drilled in western Endicott since 1980 were logged by authors of this report. A detailed log of each borehole is provided in appendix 3 . These logs contain details about sediment lithology and water-yielding potential seldom found in logs from other sources.

Mercereau Park well (BM 466).--In 1980, a test well was drilled for the USGS in Endicott's Mercereau Park, at the base of the flood-protection dike in line with South Loder Avenue and approximately across the Susquehanna River from Vestal well 1-3 (BM 63). The test well was drilled primarily to provide a detailed hydrogeologic description of the valley fill in a locality where such information was lacking. Continuous water-level measurements in February 1981 showed fluctuations in response to startup and shutdown of Endicott's well 5 (BM 89) and their well 28 (Park Well, BM 90), demonstrating aquifer continuity under confined conditions.

Tri Cities Airport wells (BM 476, 484, and 2680).- Two boreholes were drilled near the Tri Cities Airport in 1980 using a hollow-stem power auger, at sites west (BM 476) and southeast (BM 484) of the two airport runways in use at the time. Well BM 484 was drilled in an abandoned gravel pit; exposures in the 20 -foot pit wall plus split-spoon samples at 5 -foot intervals to a depth of 88 feet below the pit floor allowed for a detailed description of the upper 108 feet of unconsolidated sediment. Well BM 476 met refusal in till at 66 feet below land surface.

Well BM2680 was drilled in 2013 for the village of Endicott as part of this study; USGS personnel were present intermittently during drilling and examined cable-tool bailer samples that the driller considered representative of 5-foot intervals, although no special effort was made to withdraw samples from beyond the end of the casing and periodic heaving complicated interpretation.

Endicott test well EN-D36 (BM 775). - This test well was drilled in 2004 for Groundwater Sciences Corporation; Allan Randall was present during drilling, examined splitspoon samples collected at 2-foot intervals, and prepared a detailed well log.

\section{Seismic Surveys}

Passive seismic surveys using the horizontal-to-vertical spectral ratio (HVSR) method (Lane and others, 2008) were undertaken to supplement information from borehole records as to the depth to bedrock beneath the valley fill. The passive seismic survey technique is a geophysical method used to estimate the thickness of sediments over bedrock (Lane and others, 2008). Within valley fills consisting primarily of stratified sediments (gravel, sand, silt, clay), results calculated using the regression equation of Lane and others (2008) were compared to bedrock depths from nearby boreholes. 


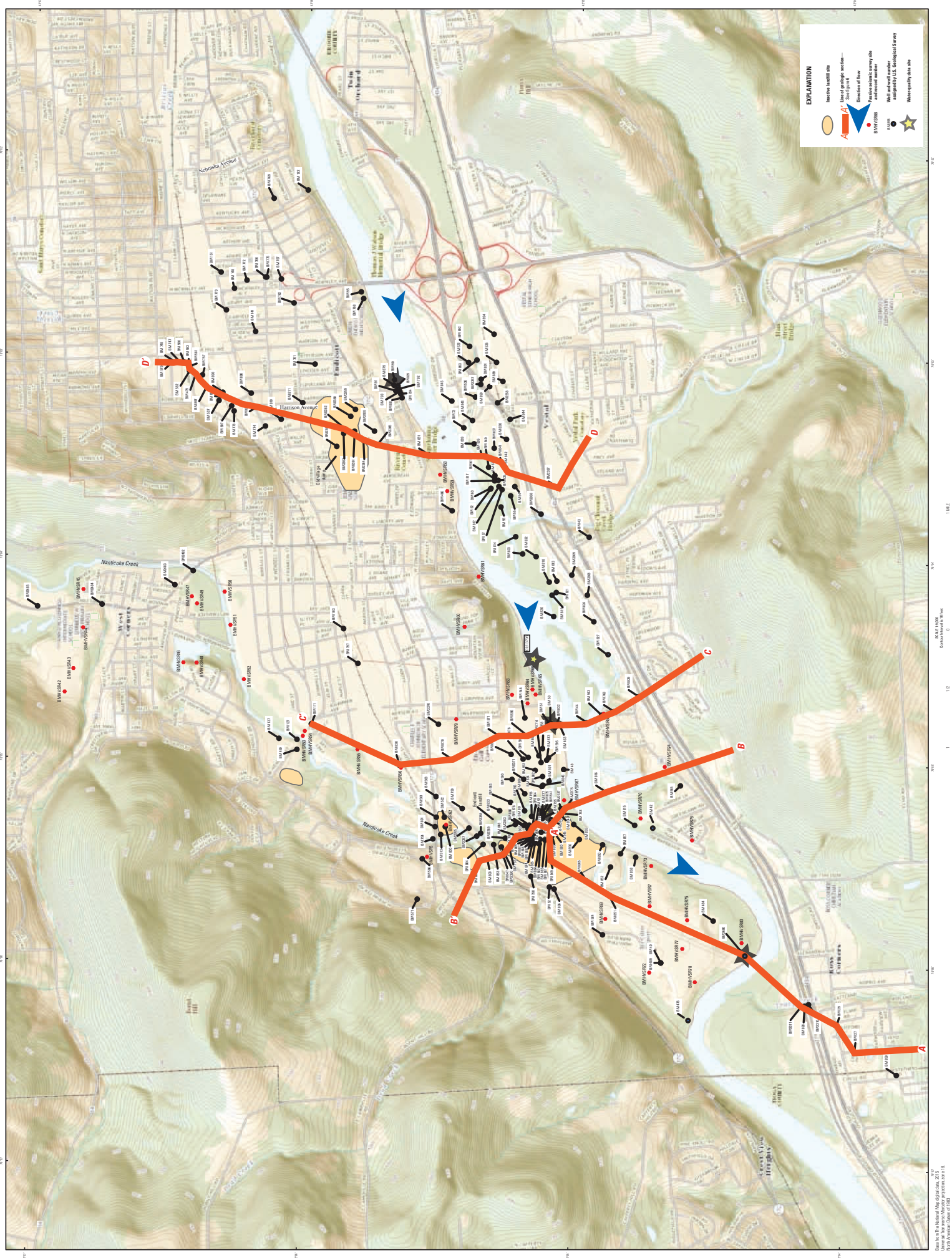

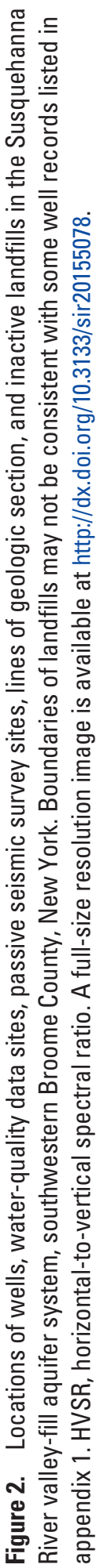


Distance between the HVSR sites and the nearest borehole ranged from more than 500 to 20 feet and averaged 255 feet. Classified as to their geographic position relative to a valley wall, depth to bedrock would be shallower nearer to the valley wall, therefore the HVSR reading would be shallower than that from a borehole located on the floor of the valley. Depth differences in areas of thin till or clay over bedrock and in the same geographic position ranged from 1 to 20 feet, whereas thick tills yield differences of 40 to more than 65 feet (fig. 3).

Altitudes of the bedrock surface at HVSR sites and at boreholes were used to draw contours of the bedrock surface (fig. 4). Each passive seismic survey site plotted in figures in this report is identified by the two-letter USGS county code, followed by HVSR to show the record is from a passive seismic survey and by a serial number, for example, "BMHVSR47".

\section{Water-Quality Data}

The USGS collected water-quality samples from Endicott well 28 (BM 90) in 2004, 2009, and 2014 as part of a groundwater-quality monitoring program conducted in cooperation with the New York State Department of Environmental Conservation. In 2014, one field blank sample and one replicate sample were collected for quality assurance.

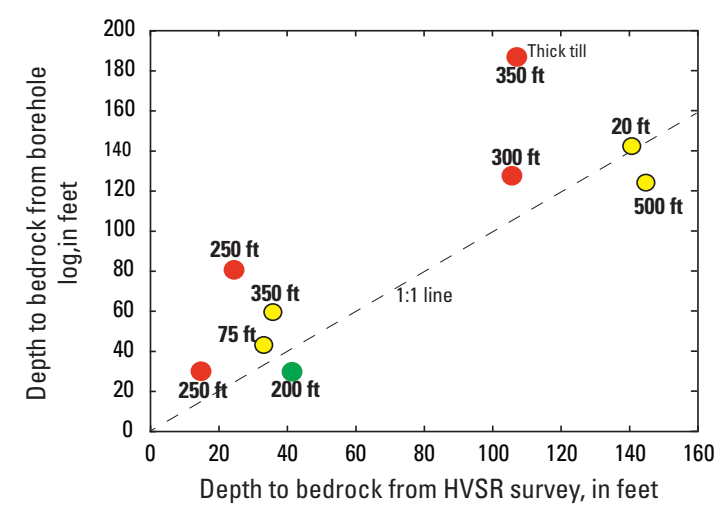

EXPLANATION

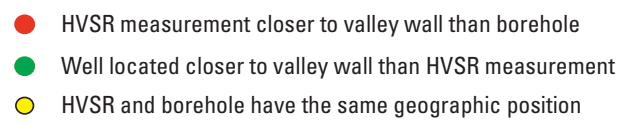

$250 \mathrm{ft}$ Approximate distance between HVSR and borehole measurements

Figure 3. Comparison of depth to bedrock estimated from horizontal-to-vertical spectral ratio (HVSR) passive seismic surveys and depth to bedrock reported from nearby wells, the distance between each well/HVSR pair, and the geographic location of each pair in the Endicott area, Broome County, New York. ft, feet.
All constituents in the blank sample were less than minimum laboratory reporting values. The variability between replicate samples was less than 20 percent for all constituents.

During the current study, water samples were collected from a newly drilled test well at the western end of the Tri Cities Airport (BM2680), from Endicott's Ranney well (BM 50), from a supplemental purge well near Nanticoke Creek (BM 541), and from the Susquehanna River several hundred feet upstream from BM 50 (USGS site number 01513706; location shown in fig. 2). Standard field-sampling protocols for water-quality testing using methods described in USGS manuals for the collection of water-quality data (U.S. Geological Survey, variously dated) were followed. The water samples were analyzed in the field for physical properties and dissolved oxygen and shipped overnight to laboratories for analysis for major ions, nutrients, metals, and trace constituents. A sample for analysis of VOCs was also collected during the current study from well BM2680. Descriptions of the analytical methods used for all constituents except the dissolved gases are available through the U.S. Geological Survey (2013a). The analytical results from all these samples are available through the USGS National Water Information System (U.S. Geological Survey, 2013b) and are also presented in appendix 4 of this report, along with 2013 VOC data from BM 50 and BM 541 as reported by the village of Endicott, which samples these wells quarterly.

\section{Hydrogeologic Setting}

Western Broome County consists largely of two fundamentally different hydrogeologic terranes: extensive uplands, where the only available aquifer is bedrock, and the deeply incised Susquehanna River valley, where bedrock is overlain by unconsolidated valley fill in which sand and gravel aquifers are commonly interbedded with non-water-yielding sediments.

The uppermost several hundred feet of bedrock consist of shales and siltstones of the West Falls Group of Late Devonian age (Rickard and Fisher, 1970). Bedrock is mantled by glacial till across most of the uplands, but is exposed at land surface in scattered localities. Bedrock layers generally dip southward at 40 to 60 feet per mile, but are locally warped into gentle folds (Wedel, 1932). Most residences and other facilities in the uplands obtain water from wells drilled into bedrock, few of which are reported to yield more than 15 gallons per minute (Randall, 1972).

Groundwater in the bedrock in upland settings is generally fresh and potable to depths of 600 to 800 feet below ridge crests, but salty at greater depths. Below the floor of the Susquehanna River valley, however, groundwater is generally salty at depths greater than 200 to 300 feet (Williams, 2010). Upward discharge of salty water from bedrock in valleys can result in chloride concentrations of several tens of milligrams per liter or more in unconsolidated sand and gravel aquifers 


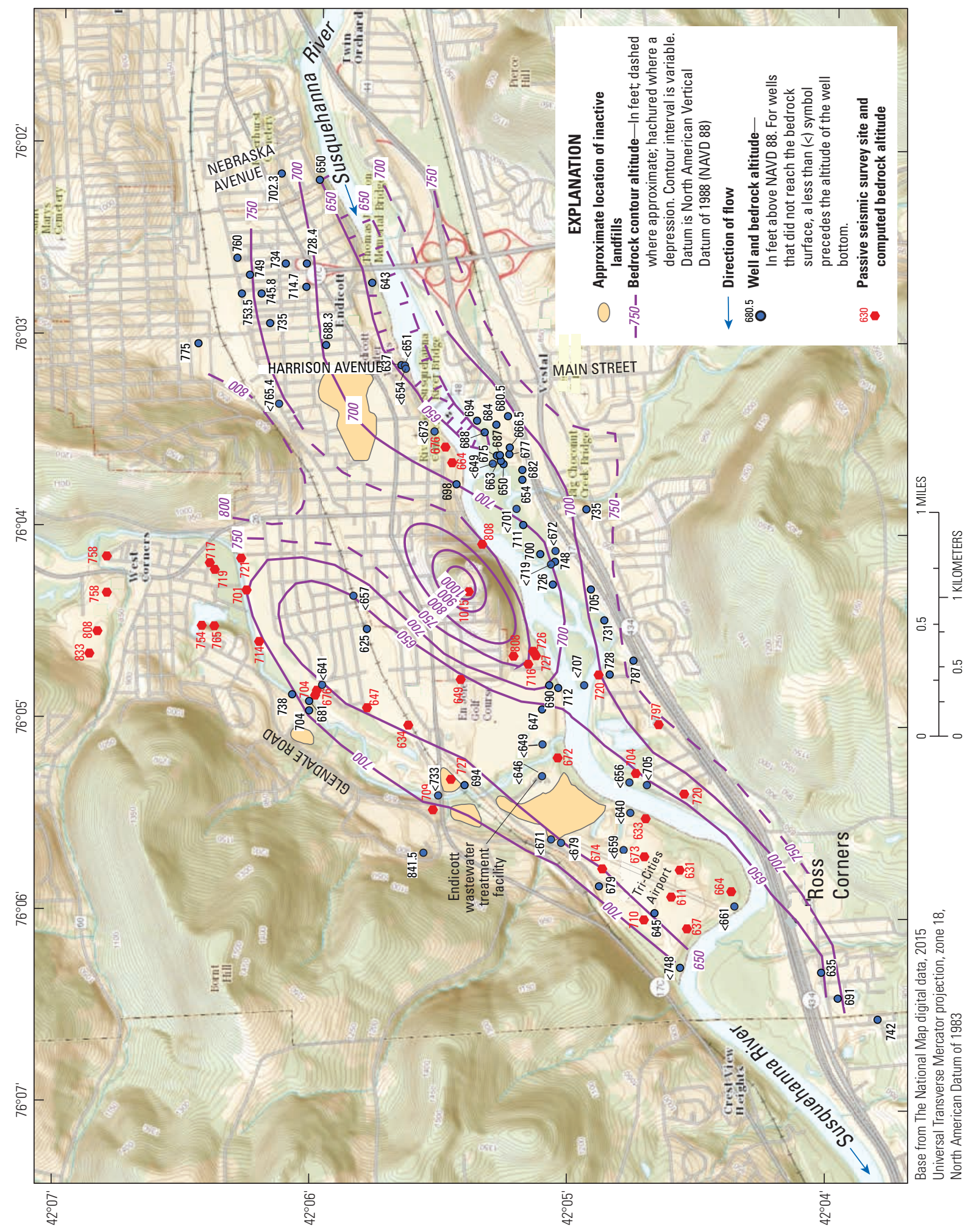

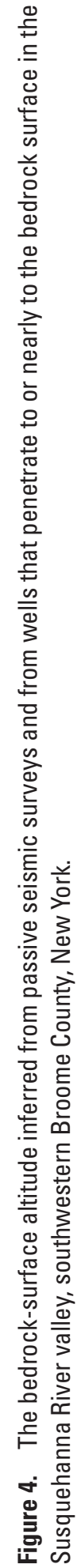


atop the bedrock, particularly where thick deposits of silt and clay overlie those aquifers and limit flushing from local recharge.

Beneath the floor of the Susquehanna River valley in Endicott and Vestal, bedrock is overlain by 30 to as much as 200 feet of unconsolidated sediment, ranging from gravel to interbedded silt and clay. The distribution and character of this unconsolidated valley fill are described in detail in the following sections on aquifer geometry.

\section{Aquifer Geometry in the Susquehanna River Valley-Fill Aquifer System}

Aquifer geometry is the product of several episodes of sediment deposition. Investigations over the past 50 years have contributed to the current interpretation, which is described below.

\section{Successive Episodes of Valley-Fill Sediment Deposition}

The unconsolidated sediments in the valley fill in southwestern Broome County were deposited in five episodes or phases. Three of these are referred to as deglacial, because the sediments were deposited by or in meltwater released as the margin of the most recent continental ice sheet was retreating by melting (deglaciation). The deglacial and postglacial episodes are time-transgressive on a regional scale; that is, the earliest episode was being deposited near the margin of the retreating ice in one locality at the same time that later episodes were being deposited farther from the ice margin (Randall, 2001). Within many localities, several successive episodes can be distinguished. Identifying the depositional episodes represented by sediments penetrated by each borehole is crucial to correlating aquifers (and confining layers) within the valley fill.

Glacial till.-Till (hardpan) was deposited from active (flowing) glacial ice throughout the uplands, and to some extent atop bedrock in the Susquehanna River valley. Till is nearly impermeable and yields little or no water to drilled wells.

Early deglacial ice-contact deposits. - Ice-contact deposits (termed kame sand and gravel in some reports) were deposited when a tongue of ice still occupied the Susquehanna River valley, by rushing meltwater streams that flowed between the ice tongue and the valley walls, and in tunnels and crevasses within the ice. Coarse to fine gravel and coarse to fine sand predominate, but range from clean (free of silt) layers that are highly permeable to dense, silty sand and gravel that yields little or no water; lenses of till also occur in some localities. Most large-capacity wells in the Triple Cities (Binghamton, Johnson City, and Endicott, N.Y.; fig. 1) tap ice-contact deposits, but because of the variability in grain size and silt content, several test wells are commonly required to locate a suitable site. In 1991, a consultant to the town of Vestal drilled eight test wells into ice-contact deposits beneath the valley floor from Choconut Creek west nearly to Castle Gardens Road (figs. 2 and 4); only two of these wells penetrated productive gravel layers deemed suitable for construction of a municipal well. This result does not necessarily mean that the ice-contact deposits in the remainder of this tract are unproductive, because drilling a few hundred feet from an unproductive site may penetrate very different materials.

Ice-contact deposits underlie terraces at 880 to 860 -foot altitudes along the south side of the Susquehanna River valley near and west of the hamlet of Vestal, and along the west side of Nanticoke Creek valley (fig. 5). Most of these terrace deposits are thinly saturated atop till or bedrock and are unlikely to yield large water supplies. However, a buried ridge of thick ice-contact deposits extends from Endwell (fig. 1, east of figs. 4 and 5) to the Tri Cities Airport and Ross Corners, beneath and generally slightly north of the present course of the Susquehanna River (fig. 5), and constitutes the principal aquifer in Endicott and Vestal. Furthermore, moderately thick ice-contact deposits underlie much of the valley floor in Vestal from Main Street west to Castle Gardens Road and probably beyond. There is also evidence that early-deglacial meltwater flow down Nanticoke Creek valley deposited permeable icecontact deposits atop bedrock from West Corners southward.

Mid-deglacial lacustrine silt and clay.-As the ice tongue in the Susquehanna River valley and the north-south trending Chenango River valley near Binghamton (fig. 1) continued to melt, the sand and gravel transported by meltwater was increasingly trapped in cavities amid the melting ice farther north, and a large lake developed in Endicott and vicinity (dammed by older valley-fill sediments down the Susquehanna River valley to the west). Thick layers of gray silt alternating with thin layers of red clay settled from the turbid meltwater onto the lake bottom. These lacustrine deposits are continuous north of the Susquehanna River from Endwell (fig. 1) to Nanticoke Creek. Where the lacustrine deposits overlap icecontact deposits, they greatly impede downward infiltration of water, and any dissolved contaminants, into the underlying ice-contact deposits. South of the river, mid-deglacial lake deposits are more localized; apparently some combination of abundant ice-contact deposits, persistent buried ice, and lesser depth to bedrock precluded the development of a large open lake.

Late-deglacial outwash.-Eventually, a brief pause in the rate of ice melting and retreat allowed meltwater to transport a flood of sand and fine gravel southward, capping the finegrained lacustrine deposits with 30 or more feet of fine to coarse sand and pebble gravel, which formed terraces in Endicott that slope westward from 850 to 830 feet in altitude. Postglacial incision of the valley fill by the Susquehanna River has left these outwash deposits largely above river level, and hence so thinly saturated that they are capable of only modest well yields despite their silt-free, highly permeable 


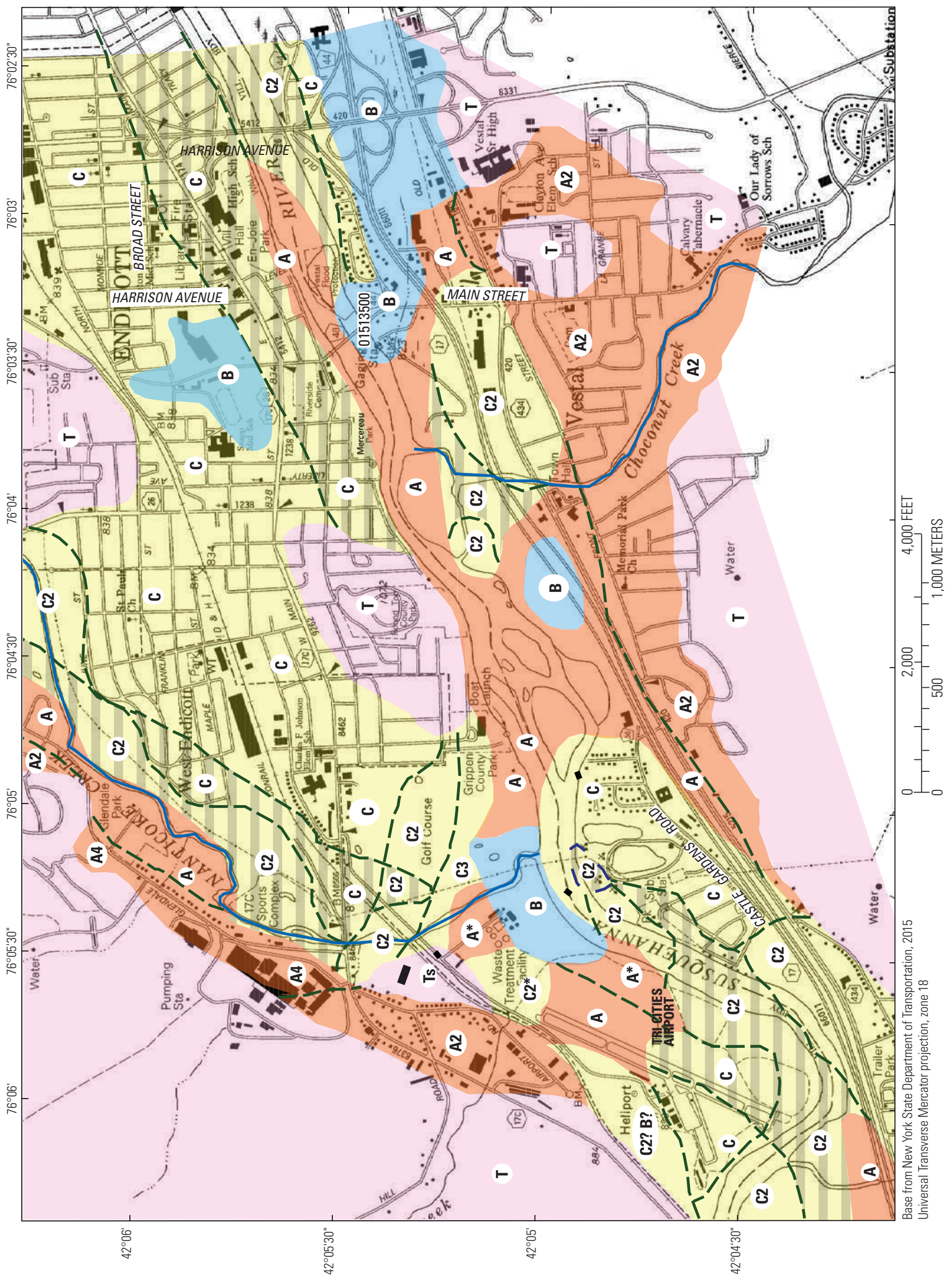




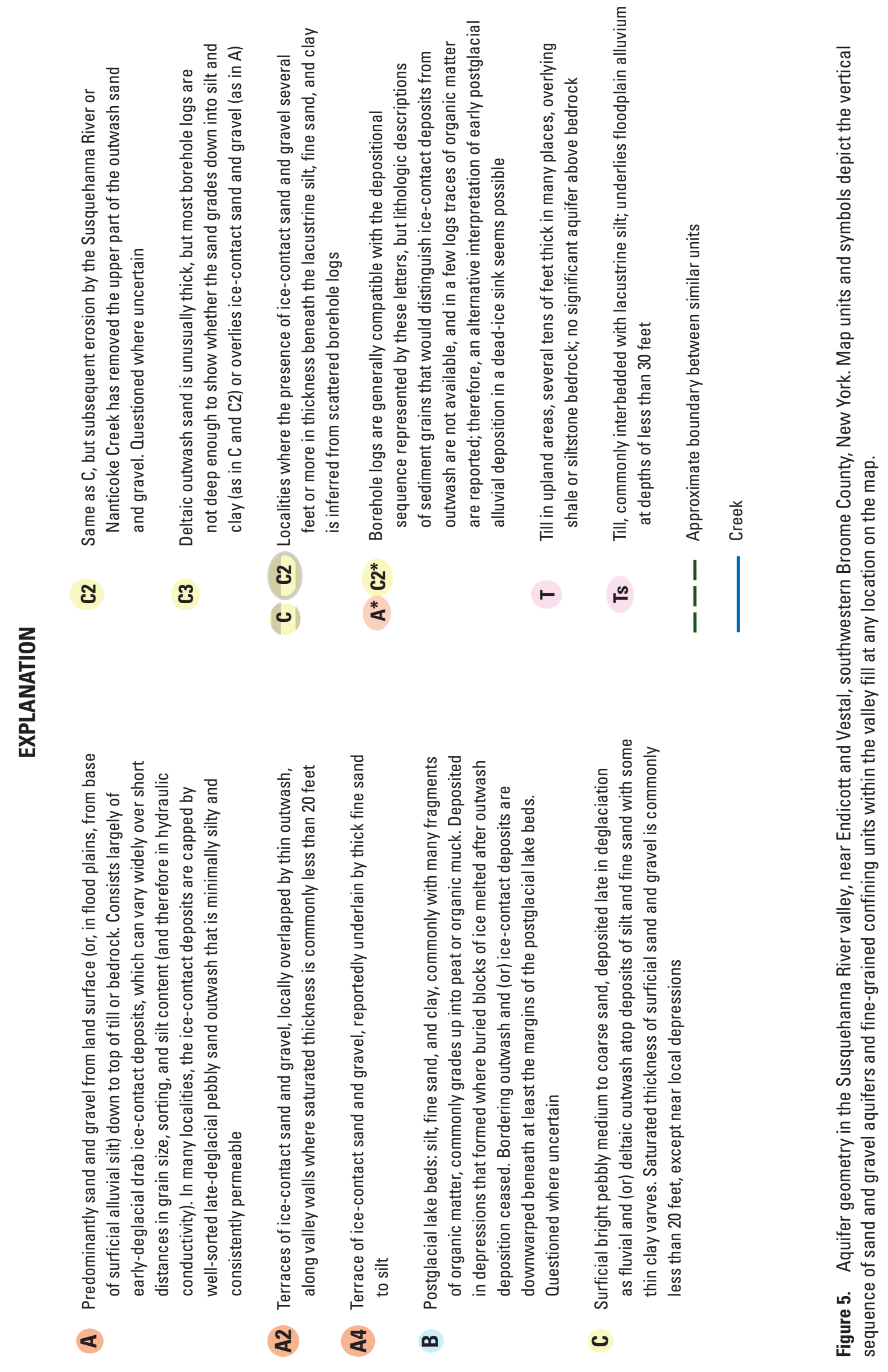


character. In a few places, where stagnant ice blocks remained buried during the episode of outwash deposition, the outwash subsequently collapsed to a lower altitude when the ice melted, and may now have sufficient saturated thickness to permit large well yields. More important, in several localities along the Susquehanna River, the outwash was deposited directly atop the ridge of ice-contact deposits, creating a hybrid aquifer favorable for infiltration of river water in response to pumping, and thus allowing large sustained well yields.

\section{Postglacial alluvium and localized organic-rich} lacustrine deposits. - After the ice margin had retreated far enough northward that meltwater no longer transported outwash into Broome County, the Susquehanna River incised the valley fill to create the modern flood plain. Alluvial sediments beneath the flood plain typically consist of 15 to 20 feet of silt and fine sand deposited during floods, overlying 5 to 10 feet of stream-channel gravel. In a few places, buried blocks of stagnant ice remained after outwash deposition ceased, resulting in lakes in ice-block depressions that formed as the ice finally melted. Peat, organic muck, and silt accumulated in these lakes; where the depressions intersected the floodplain, the organic matter typically is interbedded with silt or fine sand deposited during river floods. One such depression has been documented by numerous test boreholes in a small area near the mouth of Nanticoke Creek (fig. 5). Logs of some boreholes elsewhere in the broad floodplain near and west of Nanticoke Creek (between the Tri Cities Airport and the railroad bridge over the creek) are quite varied and not entirely consistent with the concepts stated above; this locality may have been an unusually large ice-block depression (deadice sink) filled by multiple successive river deltas early in postglacial time.

\section{Evolution of Knowledge of Aquifer Geometry}

Brown and Ferris (1946) compiled records of 88 wells and test borings in the Triple Cities, and drew several broad generalizations as to thickness and character of the valley fill. A comprehensive study of water resources in the Susquehanna River basin in New York generated several reports related to aquifer geometry. A data report (Randall, 1972) compiled records of more than 2,700 wells and test borings. Two reports included maps (at scales of 1 inch $=4$ or 5 miles) of the distribution of saturated thickness and depth of valley-fill aquifers throughout the basin; one of these reports (Hollyday, 1969) also included an analysis of typical well yields and cost of producing ground water, and the other (MacNish and Randall, 1982) included maps depicting distribution of several idealized aquifer geometries. A detailed evaluation of an aquifer in Binghamton (Randall, 1977) and two geologic reports (Randall, 1978, 1981) point out that within the Susquehanna River valley from Binghamton southwestward to the Pennsylvania border, early deglacial ice-contact deposits consist predominantly of drab fragments of local shale and siltstone, but late-deglacial outwash includes a variety of bright rock types from distant regions, a distinction that can be quite helpful in correlating buried aquifer layers.

The first detailed map of aquifer geometry within the Susquehanna River valley from Binghamton west through Endicott was prepared by Randall (1986). The map delineated three distinctive terranes - (1) sand and gravel with substantial saturated thickness, consisting of ice-contact deposits or of outwash overlying ice-contact deposits, (2) postglacial fine-grained sediments in ice-block depressions, commonly underlain by outwash, and (3) surficial outwash, saturated thickness generally less than 20 feet, overlying mid-deglacial lacustrine deposits. A digital model of the valley fill was constructed that inferred a basal aquifer of ice-contact deposits to exist everywhere beneath the mid-deglacial lacustrine deposits, although the simulated aquifer varied widely in water-transmitting capacity as constrained by well records and model calibration. Wolcott and Coon (2001) refined some computational procedures in the model and calculated contributing areas to each large-capacity municipal or commercial well, but did not alter the conceptualization of aquifer geometry.

The floor and lower sides of the Susquehanna River valley throughout the Triple Cities are largely urbanized, which has adversely affected water quality in parts of the underlying aquifers that provide municipal and industrial water supplies. Contaminants have been attributed to road salting (Randall, 1977, fig. 10), to placement of waste dumps or landfills in natural ice-block depressions, excavated pits, and other low-lying areas (Goldstein, 1981; Chin, 1990), and to leaks or spills of volatile organic compounds from industrial and commercial establishments (Ecology and Environment, 1986; Groundwater Sciences Corporation, 2013). The many test wells drilled to identify the sources and flowpaths of contaminants and to design and monitor remediation were reviewed during the current study and have led to more precise delineation of aquifer geometry. Two examples are described below.

At least 576 test wells have been drilled in eastern Endicott between Harrison and Nebraska Avenues, Watson Boulevard, and the Susquehanna River (fig. 2), where a surficial outwash aquifer overlies thick lacustrine silt and clay. Contours drawn on the top of the fine-grained lacustrine sediment (Groundwater Sciences Corporation, 2013, pl. 2-1) delineate a plateau-like surface of 830 to 820 -foot altitude, interrupted by several broad swales and smaller depressions that presumably formed where buried ice melted after outwash deposition ceased. Because the saturated thickness of the surficial outwash is substantially greater in these swales and depressions than elsewhere, they could be useful sites for production wells in the future, after contamination by VOCs has been remediated. A buried ridge of ice-contact deposits just north of the Susquehanna River has been tapped by several municipal and industrial wells. Randall (1986) had inferred that a thin gravel aquifer extended from that buried ridge north to the valley wall, below the lacustrine silt and 
atop till or bedrock, but abundant recent test-hole records (Groundwater Sciences Corporation, 2013) have demonstrated that no continuous basal gravel aquifer exists north of Broad Street and (east of the end of Broad Street) north of East Main Street (State Route 17C).

Contaminant investigations in western Endicott collectively added logs of at least 70 deep test holes to those that had been drilled to prepare for construction of Endicott's wastewater treatment facility, for which logs were published by Randall (1972). The investigation by Ground Water Associates (1992), centered on the Endicott landfill west of the wastewater treatment facility, discovered that the till atop bedrock thickens westward from less than 25 feet near Nanticoke Creek to as much as 125 feet at the base of the valley wall. All these logs provide the evidence for aquifer continuity inferred in geologic sections $A-A^{\prime}$ and $B-B^{\prime}$ in figure 6 .

\section{Delineation of Aquifer Geometry Within the Valley Fill}

The following section, along with figures 5 and 6 , describes the three-dimensional distribution of aquifers composed of saturated sand and gravel that overlie, underlie, or border non-water-yielding silt, clay, and glacial till within the unconsolidated valley-fill aquifer system of the Susquehanna River valley in western Endicott and Vestal. Four geologic sections aligned approximately north-south across the valley fill (fig. 6) depict the vertical and lateral distribution of two aquifers: outwash (also deltaic outwash in some places) and ice-contact deposits. These two aquifers are locally juxtaposed to constitute a single, thicker aquifer. Surficial alluvium, deposited on the floodplain of the postglacial Susquehanna River, typically consists of 15 to 20 feet of non-water-yielding silt and fine sand, overlying about 5 feet of river-channel gravel that functions as part of any outwash aquifer that it locally overlies.

The map of aquifer geometry (fig. 5) does not merely depict the distribution at land surface of the units delineated in the geologic sections (fig. 6). Instead, it generally infers what a well at any location on the Susquehanna River valley floor can be expected to penetrate - the surficial unit and one or more underlying units.

In areas designated as A on figure 5, 40 to 150 feet of sand and gravel are present below the water table (or below the base of alluvial silt when beneath floodplains) down to the top of bedrock, or to the top of basal till where till overlies bedrock. Ice-contact deposits that vary widely in silt content and hydraulic conductivity commonly constitute most or all of the sand and gravel, and are termed drab because they are composed predominantly of gray to olive-gray fragments of the local shale and siltstone bedrock. In some areas, however, the uppermost few tens of feet are younger outwash, which is relatively silt-free and permeable, and is termed bright because it contains a wide variety of rock fragments of various colors derived from distant locations. Multiple test wells may be needed to locate silt-free ice-contact sand or gravel layers suitable for construction of a screened large-capacity well. Soluble contaminants can readily infiltrate from land surface into the aquifers in areas designated as A (fig. 5). Where these areas extend beneath major streams, infiltration of surface water can sustain well yields of a million gallons per day or more indefinitely, as indicated by several production wells along the banks of the Susquehanna River in the study area (figs. 1 and 2; appendix 1). These wells have been pumped at 1,000 to 3,500 gallons per minute more or less continuously from the 1930s or 1940s through the 1960s and in most cases to 2014 - without serious reductions in yield during the drought of the early 1960s when the Susquehanna River was near its record low flow for months. Descriptions of sand and gravel in surface exposures and well logs as bright or drab, or more precise descriptions based on counts of the various lithologies of pebbles or sand grains, can be quite useful in correlating layers between scattered wells or exposures (Denny and Lyford, 1963; Randall 1977, 1978, 1981).

In areas designated as A2 in figure 5, terraces of icecontact sand and gravel, locally overlapped by thin outwash, are banked against the lower valley walls. Few reliable well or borehole records have been obtained in these areas, but less than 20 feet of saturated sand and gravel is thought to be typical. Soluble contaminants could readily infiltrate in these areas and migrate to more productive aquifers beneath the adjacent valley floor. Near Glendale Road west of Nanticoke Creek, A4 (fig. 4) designates a terrace reportedly underlain by thick fine sand or silt.

In areas designated as $\mathrm{C}$ or $\mathrm{C} 2$, a valley train of latedeglacial bright outwash sand and gravel caps thick middeglacial lacustrine fine sand and silt that is commonly interbedded with thin layers of pink clay. (C2 designates areas where postglacial streams incised and removed the upper part of the outwash, depositing alluvial silt and channel gravel atop the remaining outwash or fine-grained lacustrine sediments.) The surficial outwash is a widespread aquifer, but saturated thickness is generally less than 20 feet so well yields are modest. For example, 17 wells in central Endicott, 6 to 12 inches in diameter and finished with 1.5 to 11 feet of screen at depths of 14 to 47 feet, each near the base of the surficial outwash sand and gravel, were pumped throughout 2012 at average rates that ranged from 1.9 to 105.3 gallons per minute (Groundwater Sciences Corporation, 2013). In some localities, however, blocks of buried ice did not melt completely until after the flood of outwash sand and gravel ended, leaving natural depressions on the land surface where the outwash gradually collapsed to fill the void left as the remaining ice melted. The outwash sand and gravel can attain saturated thickness of 20 to 60 feet beneath such depressions, or around the margins of the depressions, so well yields of a few hundred gallons per minute are feasible and may be sustainable for months by inflow from the thinly saturated outwash that surrounds the depressions. However, many of these depressions collapsed below the water table, allowing 

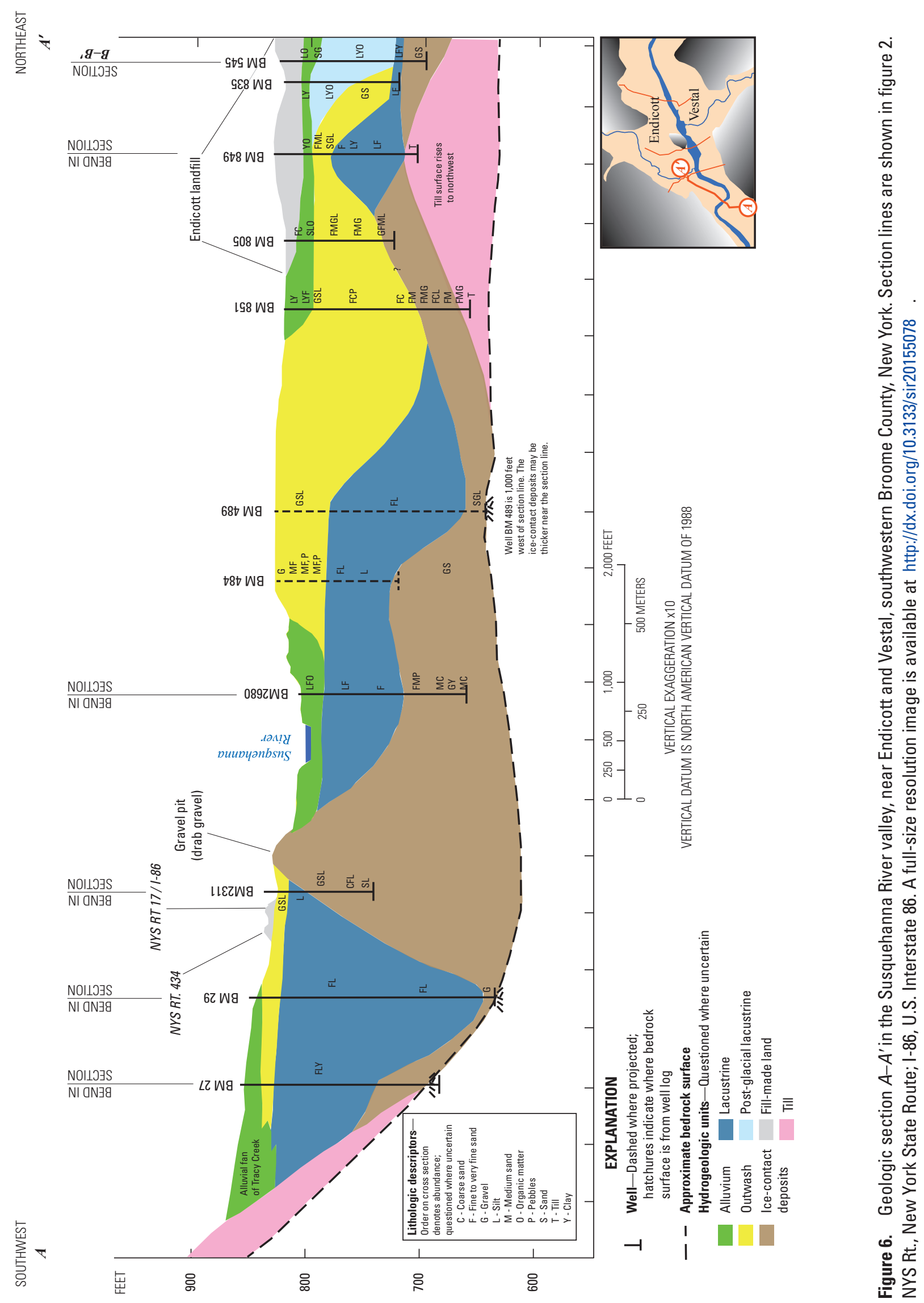


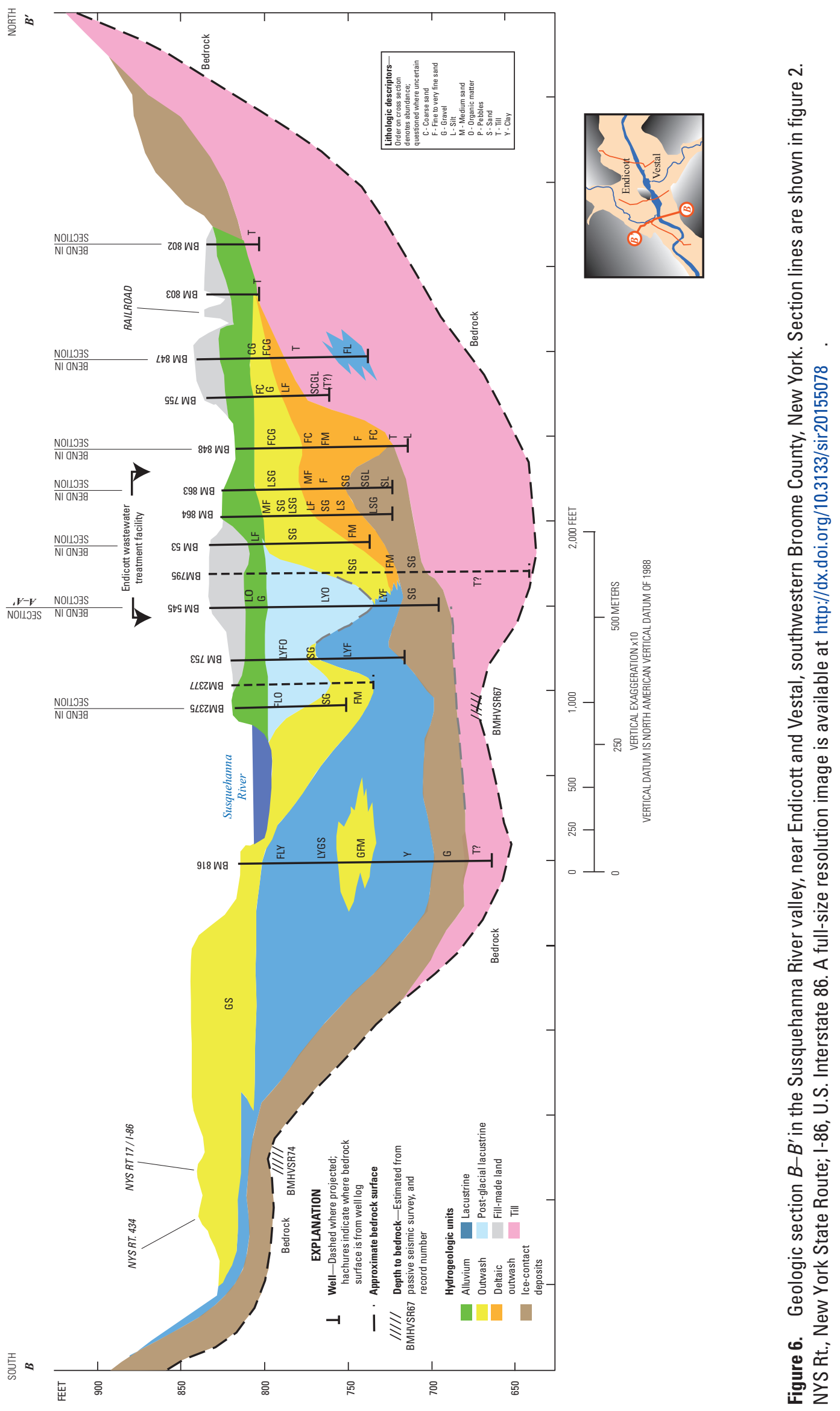




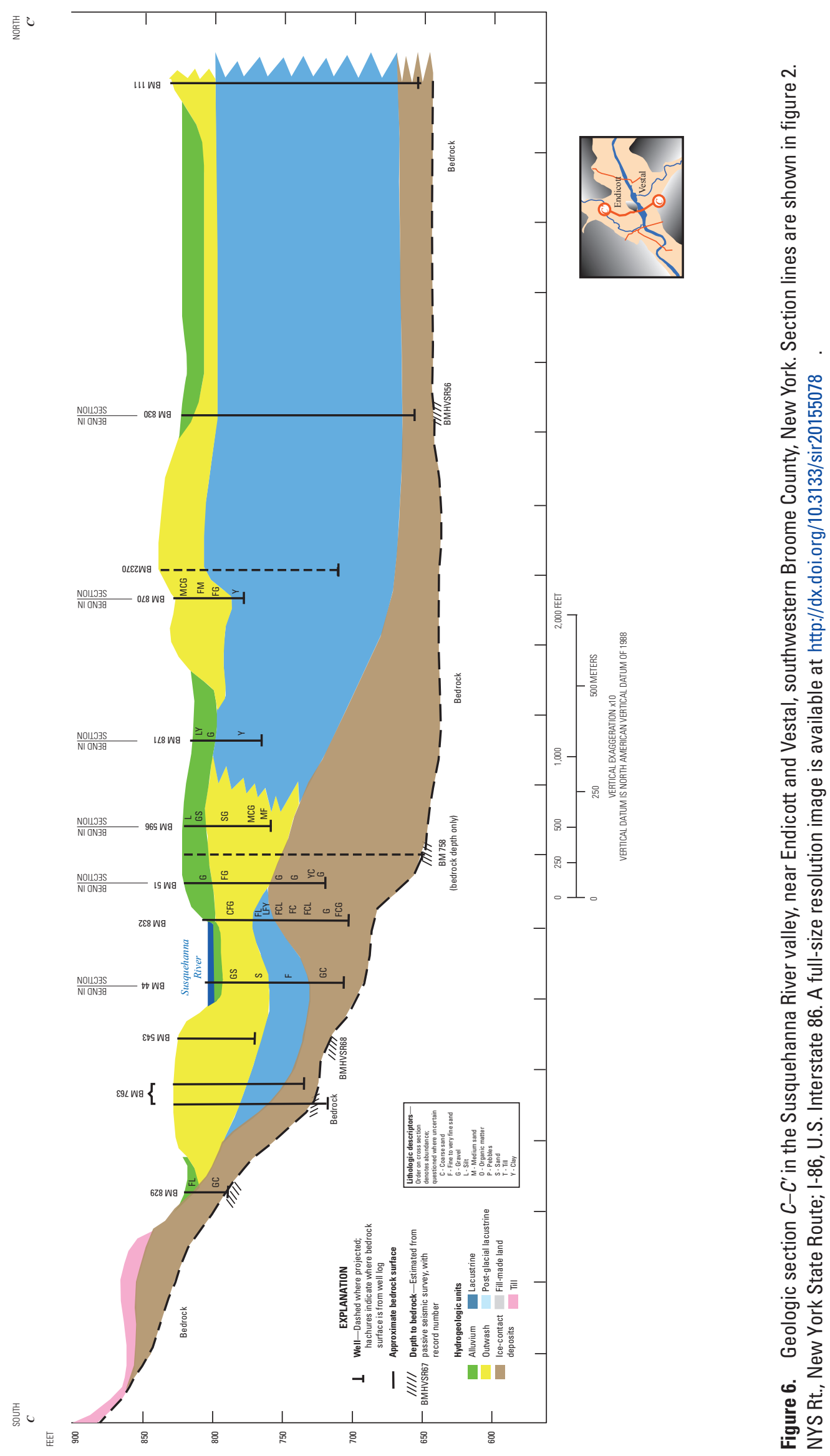




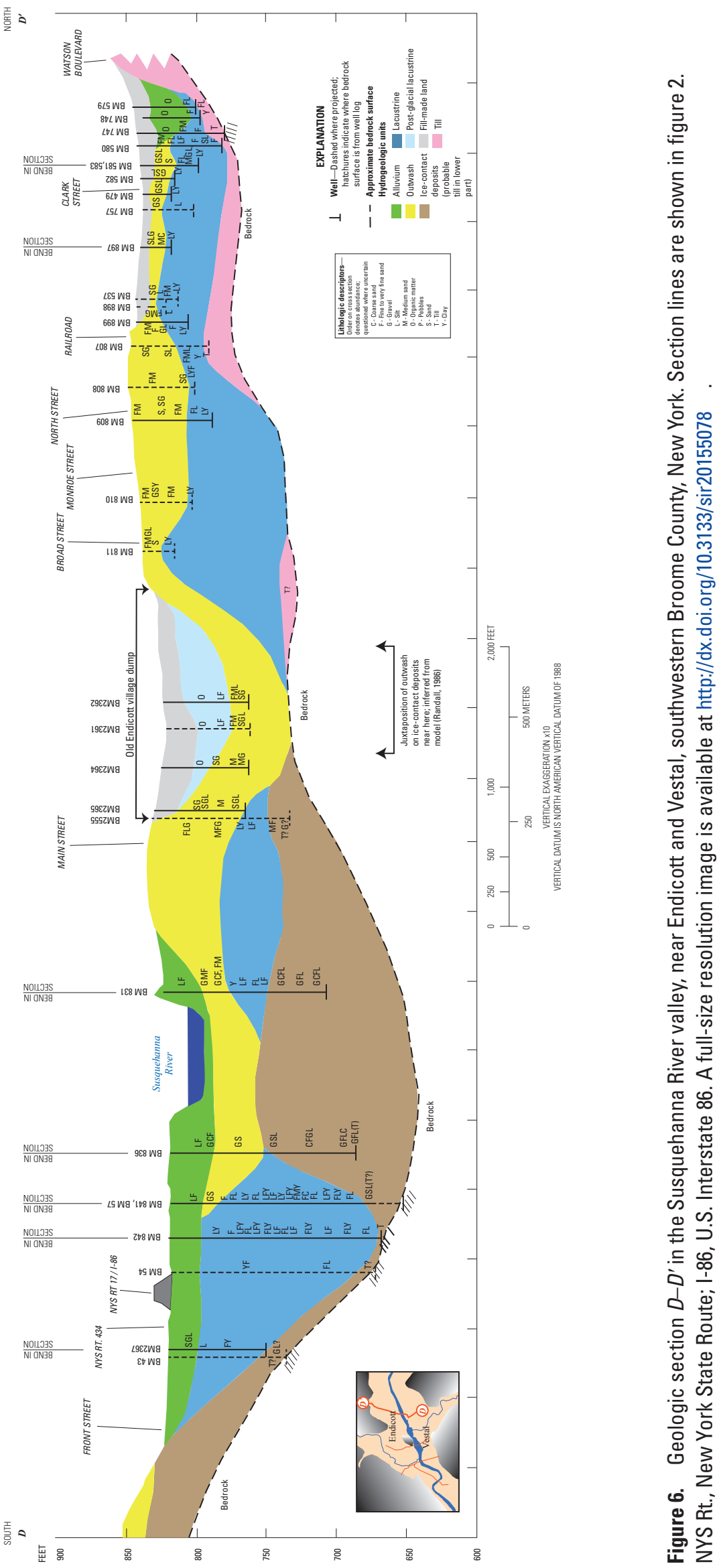


the formation of ponds or swamps in which leaves and other organic debris accumulated (see description of areas designated as B in fig. 5). The largest such depression in Endicott is near Jennie F. Snapp Middle School, immediately west of Harrison Avenue. Parts of this depression have been used for a village dump (inactive landfills figs. 2 and 4) and a shopping mall. Samples of groundwater and soil gas were collected at several locations within and bordering the depression. The samples were analyzed mainly for VOCs, several of which were detected but none above maximum allowable concentrations; foaming of two groundwater samples was attributed to decaying organic matter (Shaw Environmental and Infrastructure Engineering, 2005).

The entire C-C2 surficial aquifer (fig. 5) is readily subject to infiltration of soluble contaminants and dense nonaqueous liquids spilled at land surface. The lacustrine silt and clay that underlie this aquifer prevent further downward infiltration of contaminants. In central Endicott, severe contamination in the surficial aquifer is being remediated by introducing clean water through a network of recharge wells, meanwhile withdrawing contaminated water from nearby wells, thereby capturing nearly all contaminants rather than allowing the contaminated water to flow naturally to the river or to the few localities where the surficial outwash directly overlies the ice-contact aquifer that is tapped by municipal wells (Groundwater Sciences Corporation, 2013).

In a small area near Nanticoke Creek, designated as C3 (fig. 5), several boreholes penetrated alluvium over mostly medium-fine to medium-coarse sand suggestive of deltaic outwash to depths of 50 to 70 feet (770 to 730 -foot altitude), which is lower than the contact of outwash sand atop silt and clay (C and C2) near and north of Main Street in Endicott. Perhaps meltwater flow and transport of sand and gravel throughout deglacial time were largely concentrated south of Roundtop Hill (a till-mantled hill near the center of figs. 4 and 5), initially creating a channel filling of drab ice-contact gravel, but later building a sandy delta of bright outwash that advanced northwestward into a lake.

Areas designated as B (fig. 5) are ice-block depressions that formed or persisted later than the late-deglacial episode of outwash deposition. Depressions that were intersected by the Susquehanna River as it incised its modern floodplain, or by tributaries, are filled mostly with silt that settled from suspension in floodwaters, interspersed with organic matter and perhaps lenses of stream-channel gravel. Depressions remote from streams initially were ponds in which leaves and other organic debris accumulated, eventually transitioning to swamps or bogs. Decay of this organic matter resulted in depletion of dissolved oxygen and development of anoxic conditions that allowed iron and manganese to dissolve from the aquifer sediments. Some of these depressions were also used as dump or landfill sites (Chin, 1990). Areas designated as B (fig. 5) are unsuitable as sources of water supplies because the sediments within these depressions yield little water, and because withdrawals from any underlying or adjacent aquifer are likely to contain excessive dissolved iron, manganese and organic carbon after filtering through the organic matter, and perhaps also contaminants leached from refuse. Information in areas designated as B was inadequate to allow the distribution of underlying units within the valley fill to be inferred, but units bordering areas designated as B generally extend beneath at least the margins of those areas.

The foregoing paragraphs and figures have described a valley-fill depositional sequence that comprises the principal hydrogeologic units within the Susquehanna River valley fill:

- Till, deposited atop bedrock, generally thin or discontinuous beneath the valley floor but as thick as 125 feet near the valley wall west of Nanticoke Creek.

- Early deglacial drab ice-contact sand and gravel, deposited in terraces between ice tongues and the valley sides, and along ice crevasses or tunnels in midvalley.

- Mid-deglacial silt, fine sand, and clay deposited in a lake that formed beyond the margin of the retreating ice, commonly mantling till or ice-contact deposits.

- Late deglacial bright outwash sand and gravel deposited in deltas or stream channels, mantling earlydeglacial ice-contact deposits or mid-deglacial lake sediments.

- Postglacial alluvium, mostly silt overlying a few feet of stream-channel gravel, deposited on flood plains.

- Localized thick postglacial accumulations of silt and organic muck or peat in natural depressions that formed where the last remnants of buried ice melted.

This depositional sequence is generally applicable all along the Susquehanna River valley in the Triple Cities (Randall, 1977, 1978, 1986) and, indeed, in valleys throughout the glaciated northeastern United States (Randall, 2001). In figure 5, however, a few localities in western Endicott, near or west of Nanticoke Creek, are labelled A* or C2*, because they might contain sediment younger than similar sediments in areas labeled A or C2. None of the logs of test boreholes in these localities include information on lithology of the pebbles or sand grains that would allow definitive classification as drab or bright, and four logs mention traces of organic matter at one or more depths in what otherwise would appear to be mid-deglacial lake deposits. Perhaps sparse vegetation close to the retreating ice margin could account for rare traces of organic matter in mid-deglacial lake sediments, in which case the interpretations in figures 5 and 6 are likely to be correct in these localities. If, however, any traces of organic detritus require postglacial deposition amid a vegetated landscape, these localities must have been part of what Fleisher (1986) termed a dead-ice sink - an unusually large ice-block depression that was filled with sediment during postglacial time by multiple river floods, resulting in a complex stratigraphy that would require very detailed subsurface data to correlate. 


\section{Sources of Recharge}

In the Appalachian Plateau of New York under natural conditions, valley-fill aquifers are recharged mainly from two sources: (1) precipitation that falls on the valley floor, and (2) upland runoff, which includes (a) seepage losses from upland tributary streams where they flow across alluvial fans or kame sand and gravel after they enter a larger valley, and (b) unchanneled surface and shallow subsurface runoff from adjacent upland hillsides, which seeps into valley-fill aquifers at the base of the hillsides. These sources have been explained conceptually and approximately quantified in several reports (MacNish and Randall, 1982; Randall, 1986; Morrissey and others, 1988; Williams and Morrissey, 1997). A third source, groundwater inflow from bedrock that borders the sides and bottom of the valley fill, has been documented from water quality data in a few locations in the Appalachian Plateau but is believed to generally be of lesser magnitude than the other two sources, especially where till overlies the bedrock.

Large groundwater withdrawals from the valley-fill aquifer system along the Susquehanna River in the Triple Cities have lowered the water table below river-surface altitude, thereby inducing infiltration of water from the Susquehanna and Chenango Rivers (Randall, 1970, 1977; Yager, 1986). A digital computer model of the valley fill in a 14-mile reach of the Susquehanna River valley in southwestern Broome County was used by Wolcott and Coon (2001) to simulate groundwater withdrawal from each municipal and commercial well under steady-state conditions as of April 1981. The simulated withdrawals totaled 26.1 million gallons per day. The simulation indicated that recharge to the valley fill was derived from (1) precipitation on the valley floor (35.3 percent), (2) induced recharge from the Susquehanna and Chenango Rivers (28.5 percent), (3) seepage losses from upland tributary streams (25.1 percent), and (4) unchanneled upland runoff (11.1 percent; Wolcott and Coon, 2001, table 4). Despite the large volume of induced infiltration captured by various wells near the river bank, only one of those wells has ever discharged water containing coliform bacteria derived from the river. The bacteria were first noted in that well after a sudden rise in river stage following four months of record-low stage, and two to three years after excavation of the riverbed to construct piers for a highway bridge and to lay a pipeline beneath the riverbed, each within 200 feet of the well. Randall (1970) concluded that disruption of the natural layering within the riverbed by that excavation was chiefly responsible, and recommended that riverbed excavations be avoided near municipal wells.

\section{Groundwater Levels}

A generalized map of the water table in the Susquehanna River valley in southwestern Broome County in April 1981 was presented by Randall (1986, pl. 4). The water table generally slopes toward the Susquehanna River but includes several closed depressions surrounding large municipal or industrial wells.

\section{Water Quality}

Water samples for chemical analysis have been collected by the USGS from BM2680 (a test well drilled in 2013 near the Tri Cities Airport), BM 90 (Endicott well 28), BM 50 (Endicott Ranney well), BM 541 (Endicott supplemental purge well), and from the Susquehanna River near Endicott, New York (USGS stream measurement site 01513706, fig. 2). Analytical results are reported in appendix 4. All samples were analyzed for physiochemical properties and dissolved constituents, discussed in the following paragraphs, and for a variety of VOCs as discussed later in this report.

Wells BM 50, BM 541, and BM2680 tap ice-contact sand and gravel somewhat north of the Susquehanna River and west of Roundtop Hill. At BM 50 and BM 541, water-bearing sand and gravel is present from the base of thin surficial alluvial silt down to the top of basal till or bedrock (area A in fig. 5). At BM2680, the ice-contact deposits are overlain by thick mid-deglacial lacustrine silt capped by outwash gravel (area C in fig. 5). BM 50 has been pumped continuously since 1948 at rates of 4,000 gallons per minute or more; a substantial part of its yield is derived from induced infiltration of water from the Susquehanna River. BM2680 is remote from any large groundwater withdrawals (the nearest large-capacity well is 3,500 feet upstream and on the south side of the river), and is unaffected by induced infiltration. BM 541 (the supplemental purge well) is pumped at 375 gallons per minute; the water is treated at the adjacent wastewater treatment facility for the express purpose of capturing dissolved chemicals leached from a large municipal landfill about 600 feet to the west of the well before the chemicals travel east toward BM 714 (the initial purge well) and BM 50 (the Ranney well). These varied circumstances influence water quality in the wells.

Concentrations of most dissolved chemical constituents in samples from BM 50 and BM2680 were similar, although generally slightly higher in BM2680, which might reflect some recharge to BM2680 from the underlying bedrock and longer storage time in contact with aquifer sediments, in the absence of induced infiltration. However, water from BM 50 contained slightly higher concentrations of several nitrogen species, orthophosphate, and alkalinity (possibly attributable to use of fertilizer on the adjacent golf course), also barium, manganese, and zinc. The sample from BM 50 was generally similar to several samples collected from this well in the 1950s (Randall, 1972), but with modest increases in chloride, alkalinity, and residue. No explanation is evident for the extraordinarily high concentration of aluminum in the sample from BM2680. The sample from BM 541 contained more dissolved mineral content, as measured by specific conductance and residue at 180 degrees Celsius $\left({ }^{\circ} \mathrm{C}\right)$ and 
higher concentrations of most dissolved constituents than samples from BM 50 and BM2680. The sample from BM 541 was also characterized by unusually high concentrations of ammonia (4.8 milligrams per liter), iron (7.8 milligrams per liter), and manganese (1.3 milligrams per liter), and by negligible dissolved oxygen concentrations, which collectively document strongly reducing conditions. All these attributes are inferred to reflect an admixture of leachate from the nearby landfill (as anticipated when this well was installed).

Well BM 90 taps ice-contact deposits at a depth of 145 feet along the north bank of the Susquehanna River about 4,000 feet east of Roundtop Hill. Borehole records (appendix 1) indicate that the ice-contact deposits are confined beneath fine-grained mid-deglacial lacustrine sediments north of the river. However, aquifer modeling (Randall, 1986) and logs of a few boreholes south of the river suggest that the confining layer is discontinuous or absent beneath the river bed (fig. 5). A waterborne seismic survey of this reach of the river exhibited very little signal penetration, interpreted as due to high reflectivity of thick sand and gravel deposits beneath the river bed (Reynolds and Williams, 1988). Specific conductance, residue at $180^{\circ} \mathrm{C}$, several common inorganic constituents (calcium, magnesium, sodium, alkalinity, chloride, sulfate), also barium and strontium, were all much higher in samples from BM 90 than in BM 50 and BM2680, and increased steadily from 2005 to 2014; these results may reflect the urban environment in this locality, or may be attributed to a substantial fraction of the water in BM 90 having been derived from the deep confined aquifer to the north. The high concentrations of iron and manganese suggest reducing conditions, which seems inconsistent with the relatively high concentrations of dissolved oxygen. The water temperature of $14.9^{\circ} \mathrm{C}$ measured in September 2009 is consistent with induced infiltration from the river. Thinning or downwarping of the mid-deglacial fine-grained sediments east of BM 90 (Groundwater Sciences Corporation, 2013, pl. 2-1) might allow water from the surficial outwash aquifer to recharge the deep aquifer near BM 90. Perhaps the water pumped from BM 90 may vary over time in the proportions of old water from the deep ice-contact deposits to the north and shallow infiltration near or from the river.

Water quality values from the Susquehanna River were generally different than those from the wells, with somewhat higher nitrogen constituents and lower trace metals. Concentrations of many constituents in Susquehanna River water are inversely correlated with streamflow magnitude (Pauszek, 1959, p. 92).

\section{Volatile Organic Compounds}

VOCs " .... are ground-water contaminants of concern because of very large environmental releases, human toxicity, and a tendency for some compounds to persist in and migrate with ground-water to a drinking-water supply well .... In general, VOCs have high vapor pressures, low-to-medium water solubilities, and low molecular weights. Some VOCs may occur naturally in the environment, other compounds occur only as a result of manmade activities, and some compounds have both origins." (Zogorski and others, 2006).

Several VOCs, such as trichloroethene and its breakdown products, have degraded or threatened the quality of groundwater in the Susquehanna River valley-fill aquifer system within the Triple Cities. Sources include leaks or spills, mostly from industrial and commercial facilities, and leachate from landfills. Currently the village of Endicott operates two 'purge' wells east of the Endicott landfill near the Tri Cities Airport. The wells are pumped to capture VOCs that had been migrating to Endicott's Ranney well (BM 50, fig. 2), as discussed below. In Vestal, a former production well (BM 73, fig. 2) has been pumped into the Susquehanna River since 1980 to capture another plume of VOCs before they migrate to two production wells nearby. Other landfills and spills have been and continue to be addressed to reduce the amount of VOCs throughout the Susquehanna River valley-fill aquifer system (Groundwater Sciences Corporation, 2013).

VOCs were detected in water pumped from Endicott's Ranney well (BM 50) in 1981, which led to investigations (Adams and Grant, 1984; Grant, 1985) that documented that these contaminants approached the Ranney well from the west, through the outwash/ice-contact gravel aquifer beneath and north of poorly permeable fine-grained sediments deposited in a postglacial ice-block depression. A purge well (BM 714) was constructed in 1984 to intercept and pump to waste much of the contaminated water. A subsequent comprehensive study, summarized by Goldberg-Zoino Associates (1987), demonstrated that the organic contaminants originated near or west of the Endicott wastewater treatment facility. In the early 1980 s, more than 20 VOCs were detected in samples from the Ranney well, the purge well, and several nearby observation wells east of the landfill, the most prevalent VOCs being vinyl chloride, chloroethane, and trans 1,2-dichloroethene. The highest detected concentration of VOCs and total organic carbon, however, was in groundwater seepage from the landfill on the bank of the Susquehanna River 2,000 feet downstream from Nanticoke Creek (Goldberg-Zoino Associates, 1987). Further study (Ground Water Associates, 1992) led to construction in 1992 of a supplemental purge well (BM 541) adjacent to the landfill.

To investigate whether the aquifer tapped by the 2013 test well (BM2680) is currently influenced by any VOC sources, primarily the Endicott landfill located just west of the Endicott wastewater treatment facility, a sample was taken in January 2014 after several hours of pumping. The sample was analyzed for eight VOCs (appendix 4), including vinyl chloride, which was present in the 1980s in many groundwater samples from wells east of the landfill (Goldberg-Zoino Associates, 1987) and was present at 26.4 micrograms per liter in a 2013 sample from the supplemental purge well (BM 541) close to the landfill. The only VOC detected in the sample from the 2013 test well (BM2680) was dichloromethane, at a concentration of 0.7 microgram per liter. Dichloromethane, 
also known as methylene chloride, is a common solvent and may have been introduced into the well as a thread degreaser for the drill pipe in this newly drilled well. The lack of other VOCs suggests such a source, as does the fact that methylene chloride is only slightly soluble in water according to the U.S. Environmental Protection Agency (2000).

Each of the four wells in appendix 4 was tested for different VOCs at different levels of detection, so comparison of concentrations among wells is difficult. The relatively low concentrations of vinyl chloride, 1,1,1-trichloroethane, 1,1-dichloroethane, and cis-1,2-dichlorethene detected at BM 90 (Endicott well 28) have not been traced to a particular source, but illustrate the difficulty of preserving pristine groundwater quality in an urban environment.

\section{Prospects for Municipal Wells in Western Endicott}

The presence of highly permeable sand and gravel aquifers capable of providing an abundance of groundwater for municipal or commercial uses is inferred from aquifer geometry and borehole records in three localities in western Endicott where no large-yield wells are currently in use (fig. 7). Two of these localities are along a buried ridge of thick ice-contact deposits that borders the Susquehanna River, such that induced recharge from the river could supplement natural recharge from infiltration of precipitation and upland runoff. Unfortunately, water-quality issues have required or may require costly water treatment and (or) preventive diversions at several existing production wells in Endicott and Vestal. The risk of similar issues in these currently undeveloped localities is noted, and warrants thorough evaluation that is beyond the scope of this report.

Tri Cities Airport and vicinity.-Well and borehole records currently available suggest a potential for largecapacity municipal/commercial wells in the southwestern corner of the town of Union, near the Tri Cities Airport, and southwestward across the Susquehanna River north of Ross Corners in the town of Vestal. The airport is built on a terrace about 830 feet in altitude, composed of bright pebbly sand deposited as a deltaic valley train late in deglaciation, portions of which are also preserved at Castle Gardens in Vestal and along West Main Street in Endicott. Two wells at the airport (BM 489 and BM 585; appendix 2) were completed at the base of surficial pebbly sand, which overlies thick fine-grained lacustrine deposits. Two test holes logged by the U.S. Geological Survey (BM 484 and BM2680; appendix 2) penetrated drab ice-contact sand and gravel beneath the lacustrine deposits at an altitude of about 725 feet (section $A-A^{\prime}$, fig. $6 A$ ).

Well BM 484 was terminated only a few feet into this aquifer. BM2680 penetrated much deeper; samples provided by the driller (generally composites of multiple bailer samples from 5- or 10-foot intervals) did not distinguish any small-scale layering that may have been present, but the upper 90 feet was mostly silt to fine sand, with coarser sand and gravel, probably silty, at greater depths. A highly productive gravel layer was penetrated between 143 and 145 feet in depth, where drilling was terminated. This productive aquifer may continue somewhat deeper, as the bedrock surface (fig. 4) is inferred from other data to lie below an altitude of 650 feet, more than 11 feet below the bottom of the well. The ice-contact deposits are relatively thick near the Susquehanna River (geologic section $A-A^{\prime}$, fig. $6 A$ ) and seem to be a continuation of the buried gravel ridge that is welldocumented beneath the north bank of the Susquehanna River near South Street and Riverview Drive in Endicott (fig. 7), and near the Ranney well in West Endicott (geologic section $C-C^{\prime}$, fig. 6C).

Water quality is an important consideration in evaluating the potential of this deep aquifer. The thick and extensive lacustrine deposits that overlie the aquifer beneath the Susquehanna River and the southern part of the airport provide good protection from possible surficial contaminants. Two wells near the north end of the airport (BM 851 and BM 805, in geologic section $A-A$; fig. $6 A$ ) indicate, however, that the fine-grained lacustrine unit is absent beneath and somewhat beyond the southwest margin of the Endicott landfill. Several hundred feet farther north (at BM 849) landfill debris overlies a few feet of alluvial silty clay, and then outwash sand or gravel. Geologic section $B-B^{\prime}$ (fig. $6 B$ ) depicts the surficial outwash as thickening and directly overlying ice-contact deposits beneath the waste-treatment facility, but well logs here do not describe sediment lithology, so an alternative interpretation of thicker ice-contact deposits is also plausible. Several hundred feet to the east of geologic section $A-A^{\prime}$ (fig. 6A), near BM 858 (fig. 2), landfill debris also overlies a few feet of alluvial silty clay, below which lies thick sand and gravel of uncertain age (fig. 5). No thick, extensive layer of fine-grained sediment that would prevent infiltration of landfill leachate to the deep aquifer composed of ice-contact deposits is evident at any of these sites.

A water sample from BM2680 did not contain vinyl chloride, one of the most abundant VOCs detected in past years in wells east (downgradient) of the landfill (Adams and Grant, 1984, p. 41; Goldberg-Zoino Associates, 1987, p. 55), nor did it contain any of 7 other VOCs analyzed for. Furthermore, it did not contain elevated concentrations of ammonia such as detected in 2013 in the supplemental purge well BM 541 (appendix 4). These results are not surprising, because continuous pumping of a few thousand gallons per minute from the Ranney well (BM 50) since 1950, augmented by two purge wells in recent years, has caused eastward groundwater flow beneath the landfill site. Large withdrawals from one or more municipal wells southwest of the airport could quite possibly re-establish the natural southwestward groundwater gradient, particularly if pumping from the Ranney well and purge wells were reduced or discontinued. If the observation well at BM 851 were preserved, and a new observation well(s) with a long screen were constructed 


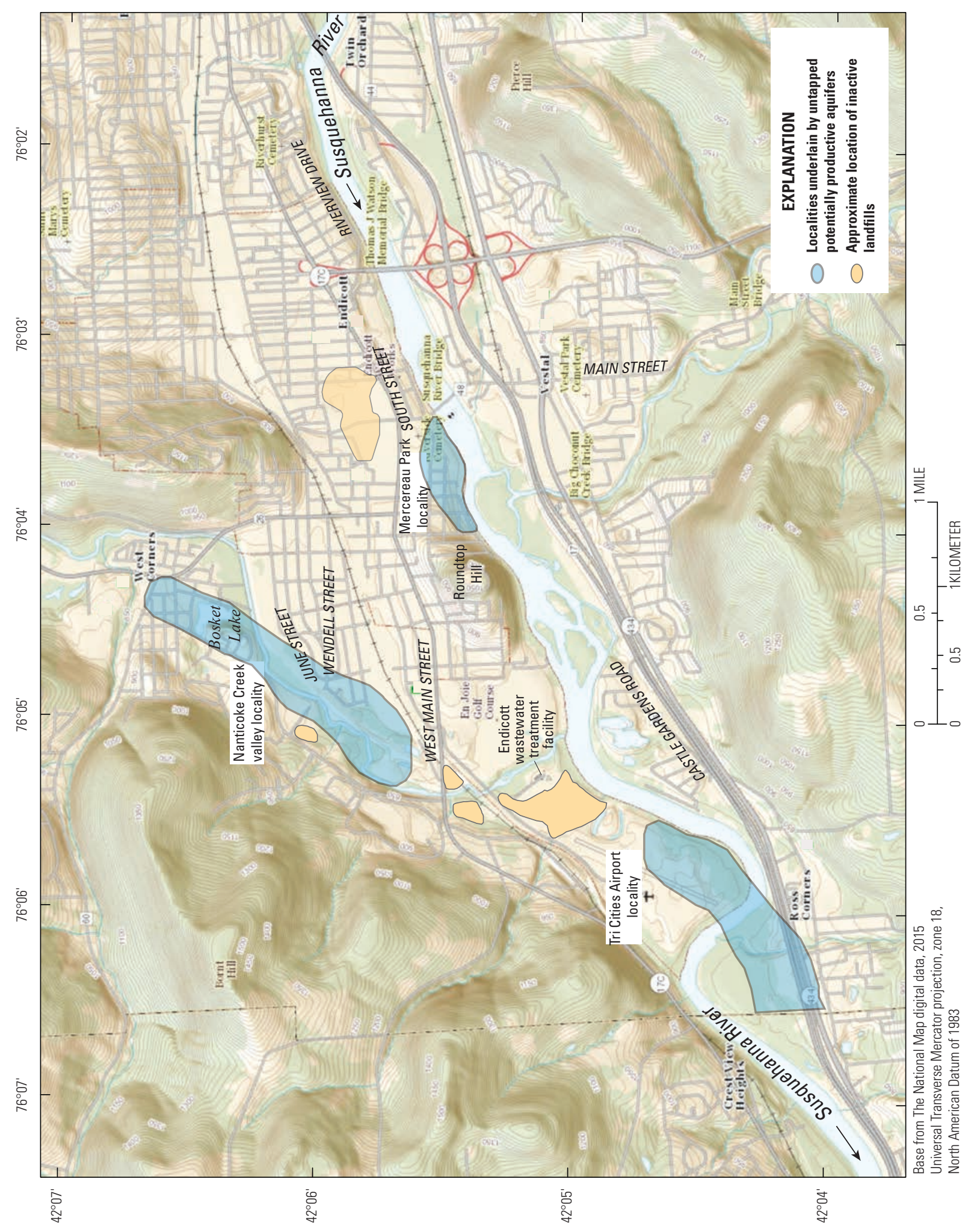

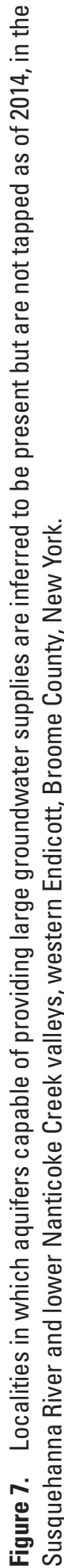


a few hundred feet east and (or) west of BM 851, sampling these wells should provide early warning of any migration of contaminants southwestward from the landfill.

Mercereau Park.-Well BM 466 penetrated generally permeable ice-contact deposits between 58 and 124 feet in depth. Bailer tests at eight depths documented yields of 30 to 40 gallons per minute through the open end of the 6-inchdiameter casing with small drawdowns (appendix 3 ). The final well, finished with 9 feet of well screen, was pumped for 1.9 hours at 5.8 gallons per minute. If well loss (drawdown due to the inefficient slotted screen and brief development) is assumed to be negligible at this low pumping rate, the calculated specific capacity of 38.6 gallons per minute per foot of drawdown could be extrapolated to 250 gallons per minute at a drawdown of 6.5 feet, which is a reasonable approximation of what could have been achieved by a 6-inch well with 11 feet of properly developed wire-wound screen at this site. A well of larger diameter with a longer screen should be capable of a much larger yield. Water samples analyzed by the Endicott Water Department in April 1981 revealed hard water free of iron. Samples collected in March 1982 were analyzed for 129 U.S. Environmental Protection Agency priority pollutants (VOCs and many other organic compounds, pesticides, metals); concentrations of only one VOC and three metals were above detection limits.

Since 1980, Vestal production well 1-1 (BM 73), located across the Susquehanna River and 1,600 feet east (upstream) from BM 466, has been pumped continuously into the river to capture a contaminant plume from the southeast and prevent migration of that plume to other Vestal production wells. Any proposal to withdraw groundwater for public supply from Mercereau Park should evaluate whether such withdrawal might alter groundwater gradients enough to draw this contaminant plume to the proposed new well(s).

Nanticoke Creek valley north of West Main Street.During deglaciation, Nanticoke Creek carried meltwater from ice that stagnated and melted in its 111 square-mile watershed. Unlike the Chenango and Susquehanna Rivers, however, it did not receive additional meltwater from subglacial and superglacial melting many tens of miles to the north. The deep east-west valley immediately north of Nanticoke Creek watershed would have shunted sediment-laden meltwater from regions to the north eastward to tributaries of the Susquehanna River upstream from Binghamton. Therefore, it is not surprising that Kreitinger and Kappel (2014) concluded that most of Nanticoke Creek valley does not contain gravel aquifers capable of sustaining large-capacity municipal wells. However, there is some evidence that suggests a productive aquifer may be present near and south of West Corners. The 1976 U.S. Geological Survey Endicott 7.5-minute topographic quadrangle map depicts a curved ridge 1,000 feet long immediately west of Bosket Lake (fig. 7), mapped as Chenango and Howard soils (Giddings and Flora, 1971), which are derived from sand and gravel. The ridge (which apparently has been mined away since 1976) crested at 880-foot altitude, about the same altitude as a narrow kame terrace along the west side of Nanticoke Creek valley farther south, and likely was part of a channel within the decaying glacial ice in which rapid meltwater flow deposited gravel.

A domestic well south of Bosket Lake, on or adjacent to the site of this ridge, was reported to obtain water from sand and gravel at a depth of about 50 feet. Test wells BM 450 and BM 127, drilled in 1960 and 1967 near Wendell Street, just west of Nanticoke Creek, and BM 137, 500 feet to the north along the creek, penetrated 20 feet of alluvial silty sand, then predominantly gravel and fine to coarse sand down to bedrock at depths of 74 to 132 feet. BM 111, a screened municipal well at the intersection of Wendell and June Street, penetrated surficial outwash gravel, then 130 feet of silt and clay over 15 to 24 feet of water-yielding sand and gravel atop bedrock; the well was test-pumped at 1,500 gallons per minute for 3 days before the screen collapsed due to excessively vigorous development. BM 830, along the railroad north of Main Street, yielded 40 gallons per minute from a depth of 168 feet through an open-end casing of 5-inch diameter.

Water from the domestic well south of Bosket Lake requires treatment to remove iron (probably a result of reducing conditions due to infiltration of water into the aquifer through organic matter accumulated on the bottom of the lake). Water from well BM 450, near Wendell Street, contained 4.6 milligrams per liter of iron, 120 milligrams per liter of chloride, and 618 milligrams per liter of hardness as $\mathrm{CaCO}_{3}$. These concentrations may represent natural water quality in the aquifer, or may reflect infiltration from a small landfill a few hundred feet upslope to the west. Water from BM 830 contained 40 to 60 milligrams per liter of chloride in 1979.

There is little evidence of any productive aquifer deposited by meltwater flow beneath the ice early in deglaciation north of Roundtop Hill. Six boreholes 2,000 to 3,000 feet east of Nanticoke Creek were reported to penetrate 120 feet or more of fine sand to clay; two of these boreholes reached bedrock, one of which penetrated 3 feet of wateryielding gravel atop bedrock. Thin, perhaps discontinuous basal aquifers may be present more than 2,000 feet east of Nanticoke Creek, but are likely to be recharged primarily from the underlying bedrock, and thus might have high chloride concentrations and reducing conditions.

\section{Summary}

The floor of the 1-mile-wide Susquehanna River valley in southwestern Broome County, New York is underlain by a valley-fill aquifer system consisting of as much as 200 feet of unconsolidated glacial and postglacial sediments, including productive gravel aquifers capable of yielding 1 million gallons per day or more to individual wells. Numerous well and borehole records, compiled in studies by the U.S. Geological Survey and many consulting firms and summarized in appendix 1, document aquifer geometry within 
this valley fill, which includes six depositional episodes that constitute hydrogeologic units:

- Till (hardpan), deposited from the moving ice directly atop bedrock, generally 0 to 25 feet thick but constituting a ramp or wedge as much as 125 feet thick at the base of the bedrock valley wall west of Nanticoke Creek.

- Ice-contact sand and gravel, deposited early in deglaciation by meltwater streams along the valley sides in terraces that are now mostly unsaturated, and in crevasses or tunnels in the ice in midvalley that now constitute the principal valley-fill aquifers. Ice-contact deposits vary widely over short distances from silty and poorly permeable, to silt-free and highly permeable.

- Lacustrine silt and clay, deposited in a mid-deglacial lake, extending continuously from Endwell to West Endicott in the northern part of the valley fill atop till, bedrock, or (locally) a few feet of ice-contact deposits. The silt and clay are also present discontinuously atop ice-contact deposits near and south of the River.

- Outwash sand and gravel, deposited late in deglaciation atop the lacustrine sediments, also directly atop relatively thick ice-contact deposits in a few localities near and south of the river. Outwash constitutes a surficial aquifer but its saturated thickness is commonly less than 20 feet, which limits well yields.

- Alluvium, beneath flood plains of the postglacial Susquehanna River and tributaries, typically consisting of 15 to 20 feet of silt over thin stream-channel gravel.

- Localized postglacial lacustrine silt with organic muck or peat, deposited in natural depressions that formed as remnant ice blocks melted.

A map (fig. 5) and four geologic sections (fig. 6) depict the distribution of these units.

Recharge to aquifers in the valley fill is derived from four sources, as follows; precipitation on the valley floor (35.3 percent), seepage losses from tributary streams (25.1 percent), unchanneled runoff from upland hillsides (11.1 percent), and recharge from the Susquehanna River induced by pumping wells ( 28.5 percent); the percentage from each source is quoted from a groundwater-flow model of the Susquehanna River valley-fill aquifer system from Binghamton west to Endicott (Wolcott and Coon, 2001).

Water samples were collected for comprehensive chemical analysis from four wells owned by the village of Endicott. One of these wells was sited adjacent to a landfill to capture water contaminated by landfill leachate; water from this well contained high concentrations of ammonia, iron, and manganese, negligible dissolved oxygen (all of which document strongly reducing conditions), 26.4 micrograms per liter of vinyl chloride, and substantial concentrations of many other dissolved constituents. Most constituents were much less abundant or not detected in water from two wells in sparsely developed localities in western Endicott. One of these wells receives induced infiltration from the river and the other penetrates an undeveloped aquifer confined beneath thick lacustrine silt, but concentrations of most constituents were similar.

Three localities are identified wherein thick ice-contact sand and gravel aquifers, deemed capable of supplying several hundred gallons per minute to screened wells, are documented or inferred from borehole records, but are not currently tapped by large-capacity wells. In each locality, poorly permeable lacustrine silt and clay overlie the ice-contact deposits, which should protect the aquifer from contaminants that might be introduced nearby at land surface. However, sources or plumes of contaminated water or naturally occurring elevated iron concentrations are known to exist a few thousand feet away from each locality. Quantitative evaluation of these risks to potential new large-capacity wells is beyond the scope of this study, but would be appropriate if new public water supplies are contemplated.

\section{Acknowledgments}

The authors would like to acknowledge the assistance of Margaret Phillips of the USGS for the construction and ongoing updating of the table of well records and input of new and old well data to the USGS National Water Information System. The authors also acknowledge the assistance of James Reddy of the USGS for the development of the geographic information system maps and figures used in this report.

\section{References Cited}

Adams, J.E., and Grant, A.F., 1984, A hydrogeologic investigation of chlorinated hydrocarbon contamination of the Ranney collector well, village of Endicott, New York: New York Department of Environmental Conservation, Division of Water, $75 \mathrm{p}$.

Brown, R.H., and Ferris, J.G., 1946, Progress report on ground-water resources of the southwestern part of Broome County, New York: New York Water Power and Control Commission Bulletin GW-15, 91 p.

Chin, G.L., 1990, Hydrogeology of landfills and waste disposal sites in Broome County, New York: Binghamton, N.Y., State University of New York at Binghamton, unpublished master's thesis, $90 \mathrm{p}$.

Clough Harbour Associates, 2008, Interim status report of the town of Vestal water resource study: Albany, N.Y., Clough Harbour Associates Project 16789, [n.p.].

Denny, C.S., and Lyford, W.H., 1963, Surficial geology and soils of the Elmira-Williamsport region, New York- 
Pennsylvania: U.S. Geological Survey Professional Paper 379, 60 p. [Also available at http://pubs.er.usgs.gov/ publication/pp379.]

Ecology and Environment, Inc., 1986, Draft remedial investigation report on water supply well 1-1 site, Vestal, New York: Buffalo, N.Y., Ecology and Environment, Inc., [variously paged].

Fleisher, P.J., 1986, Dead-ice sinks and moats-Environments of stagnant ice deposition: Geology, v. 14, no. 1, p. 39-42.

Giddings, E.B., and Flora, D.F., 1971, Soil survey of Broome County, New York: U.S. Department of Agriculture Soil Conservation Service, $95 \mathrm{p}$.

Goldberg-Zoino Associates, 1987, Remedial investigation report Endicott wellfield site, Endicott, New York: Buffalo, N.Y., Goldberg-Zoino Associates of New York, P.C., 89 p. plus figures and 7 appendices.

Goldstein, Kenneth, 1981, Register of hazardous waste dump sites, Broome County, New York: Binghamton, New York, State University of New York, Department of Geography, $58 \mathrm{p}$.

Grant, A.F., 1985, Analysis of ground water flow and purge well system performance in the contaminated aquifer supplying the Ranney well, village of Endicott, New York: New York Department of Environmental Conservation, Division of Water, $49 \mathrm{p}$.

Ground Water Associates, 1992, Endicott wellfield site remedial investigation/feasibility study: Westerville, Ohio, Ground Water Associates, 20 p. plus appendixes.

Groundwater Sciences Corporation, 2013, Combined groundwater report for 2012, village of Endicott/town of Union, Broome County, New York: Harrisburg, Pa., Groundwater Sciences Corporation, [n.p.].

Hollyday, E.F., 1969, An appraisal of the ground-water resources of the Susquehanna River basin in New York: U.S. Geological Survey Open-File Report 69-128, 52 p. [Also available at http://pubs.er.usgs.gov/publication/ ofr69128.]

Kreitinger, E.A., and Kappel, W.M., 2014, Hydrogeology of the Nanticoke Creek valley-fill aquifer, Endicott, New York: U.S. Geological Survey Scientific Investigations Report 2014-5063, 19 p., http://pubs.usgs.gov/sir/2014/5063/.

Lane, J.W., Jr., White, E.A., Steele, G.V., and Cannia, J.C., 2008, Estimation of bedrock depth using the horizontalto-vertical (H/V) ambient-noise seismic method, in Symposium on the Application of Geophysics to Engineering and Environmental Problems, April 6-10, 2008, Philadelphia, Pa., Proceedings: Denver, Colo., Environmental and Engineering Geophysical Society, 13 p.

Lozier/Ground Water Associates, 1978, Report to village of Endicott, New York-Hydrological evaluation of existing well system and recommendations for development of an improved ground water system: Westerville, Ohio, Ground Water Associates, 35 p. plus figures and tables.

Lozier/Ground Water Associates, 1992, Endicott wellfield site remedial investigation/feasibility study - Draft remedial investigation report: Westerville, Ohio, Ground Water Associates, 128 p. plus 8 pls. and 7 appendixes.

MacNish, R.D., and Randall, A.D., 1982, Stratified-drift aquifers in the Susquehanna River basin, New York: New York State Department of Environmental Conservation Bulletin 75, 68 p., plus 1 plate in 2 sheets. [Also available at http://onlinepubs.er.usgs.gov/djvu/Misc/nydec_bull_75. djvu.]

Martin, R.J., Coates, D.R., and Timofeeff, N.P., 1983, Well field contamination investigation-Report to town of Vestal: Binghamton, N.Y., R.J. Martin Consulting Engineers, 92 p. plus appendixes

Morrissey, D.J., Randall, A.D., and Williams, J.H., 1988, Upland runoff as a major source of recharge to stratified drift in the glaciated Northeast, in Randall, A.D., and Johnson, A.R,. eds., The northeast glacial aquifers: American Water-Resources Association Monograph Series 11, p. 17-36.

Munsell, A.H., 1975, Soil color charts: Baltimore, Md., Munsell Color Company, 50 p.

Pauszek, F.H., 1959, Chemical quality of surface waters in the Allegheny, Genesee, and Susquehanna River basins, New York, 1953-56: New York Department of Commerce, 94 p.

Randall, A.D., 1970, Movement of bacteria from a river to a municipal well-A case history: Journal American Water Works Association, v. 62, no. 11, p. 716-720.

Randall, A.D., 1972, Records of wells and test borings in the Susquehanna River basin, New York: New York State Department of Environmental Conservation Bulletin 69, 92 p. [Also available at http://onlinepubs.er.usgs.gov/djvu/ Misc/nydec bull_69.djvu.]

Randall, A.D., 1977, The Clinton Street-Ballpark aquifer in Binghamton and Johnson City, New York: New York State Department of Environmental Conservation Bulletin 73, 87 p. [Also available at http://onlinepubs.er.usgs.gov/djvu/ Misc/nydec_bull_73.djvu.]

Randall, A.D., 1978, A contribution to the late Pleistocene stratigraphy of the Susquehanna River valley of New York: New York State Education Department Empire State Geogram, v. 14, no. 2, p. 2-15.

Randall, A.D., 1981, Hydrology in relation to glacial geology along the Susquehanna River valley, Binghamton to Owego, New York, in New York State Geological Association 53d annual meeting, Binghamton, N.Y., Enos, Paul, ed., Guidebook for field trips in south-central New York: New York State Geological Association, p. 147-169.

Randall, A.D., 1986, Aquifer model of the Susquehanna River valley in southwestern Broome County, New 
York: U.S. Geological Survey Water-Resources Investigations Report 85-4099, 38 p. [Also available at http://pubs.er.usgs.gov/pubs/wri/wri854099.]

Randall, A.D., 2001, Hydrogeologic framework of stratifieddrift aquifers in the glaciated northeastern United States: U.S. Geological Survey Professional Paper 1415-B, 179 p. [Also available at http://pubs.er.usgs.gov/publication/ pp1415B.]

Reynolds, R.J., and Williams, J.H., 1988, Continuous seismicreflection profiling of glacial drift along the Susquehanna, Chemung, and Chenango rivers, south-central New York and north-central Pennsylvania, in Randall, A.D., and Johnson, A.I., eds., The northeast glacial aquifers: American Water Resources Association Monograph Series 11, p. 83-104.

Rickard, L.V., and Fisher, D.W., 1970, Geologic map of New York, Finger Lakes sheet: New York State Museum and Science Service Map and Chart Series no. 15, scale 1:250,000.

Shaw Environmental and Infrastructure Engineering, 2005, Final investigation report old village dump, Jennie F. Snapp School and tannery sewer NYS-DEC area-wide study Endicott, New York: Latham, N.Y., Shaw Environmental and Infrastructure Engineering of New York, P.C., 40 p. plus figures and appendixes.

U.S. Environmental Protection Agency, 2000, Methylene chloride (dichloromethane): U.S. Environmental Protection Agency Air Toxics Web site, accessed August 2014, at http://www.epa.gov/ttn/atw/hlthef/methylen.html.

U.S. Environmental Protection Agency, 2011, 2011 edition of the drinking water standards and health advisories: U.S. Environmental Protection Agency EPA 820-R-11-002, 12 p., accessed March 2013, at http://water.epa.gov/action/ advisories/drinking/upload/dwstandards2011.pdf.

U.S. Geological Survey, 2013a, National water quality laboratory: U.S. Geological Survey National Water Quality Laboratory Web site, accessed January 2013, at http://nwql.usgs.gov/.

U.S. Geological Survey, 2013b, USGS water data for New York: U.S. Geological Survey National Water Information
System Web interface, accessed January 2013, at http://waterdata.usgs.gov/ny/nwis/nwis.

U.S. Geological Survey, [variously dated], National field manual for the collection of water-quality data: U.S. Geological Survey Techniques of Water-Resources Investigations, book 9, chaps. A1-A9, accessed December 5, 2012, at http://pubs.water.usgs.gov/twri9A/.

Wedel, A.A., 1932, Geologic structure of the Devonian strata of south-central New York: New York State Museum Bulletin 294, 74 p.

Williams, J.H., 2010, Evaluation of well logs for determining the presence of freshwater, saltwater, and gas above the Marcellus shale in Chemung, Tioga, and Broome Counties, New York: U.S. Geological Survey Scientific Investigations Report 2010-5224, 27 p., http://pubs.usgs. gov/sir/2010/5224/.

Williams, J.H., and Morrissey, D.J., 1997, Recharge of valleyfill aquifers in the glaciated Northeast from upland runoff, in Ritchey, J.D., and Rumbaugh, J.O, eds., Subsurface fluidflow (ground water and vadose zone) modeling: American Society for Testing and Materials STP 1288, p. 97-113.

Wolcott, S.W., and Coon, W.F., 2001, Simulation of a valleyfill aquifer system to delineate flow paths, contributing areas, and traveltime to wellfields in southwestern Broome County, New York: U.S. Geological Survey WaterResources Investigations Report 01-4171, 25 p. [Also available at http://ny.water.usgs.gov/pubs/wri/wri014171/.]

Yager, R.M., 1986, Simulation of ground-water flow and infiltration from the Susquehanna River to a shallow aquifer at Kirkwood and Conklin, Broome County, New York: U.S. Geological Survey Water-Resources Investigations Report 86-4123, 70 p. plus plates. [Also available at http://pubs.er.usgs.gov/pubs/wri/wri864123.]

Zogorski, J.S., Carter, J.M., Ivahnenko, T., Lapham, W.W., Moran, M.J., Rowe, B.L., Squillace, P.J., and Toccalino, P.L., 2006, The quality of our Nation's waters-Volatile organic compounds in the Nation's ground water and drinking-water supply wells: U.S. Geological Survey Circular 1292, 101 p. [Also available at http://pubs.usgs.gov/circ/circ1292/.] 
Appendix 1. Tabulated Records of Wells and Test Holes in the Susquehanna River Valley-Fill Aquifer System, Southwestern Broome County, New York

[Excel table available at http://dx.doi.org/10.3133/sir20155078]

Appendix 2. Map of Records of Wells and Test Holes in the Susquehanna River Valley-Fill Aquifer System, Southwestern Broome County, New York

[Google Earth KMZ map available at http://dx.doi.org/10.3133/sir20155078]

Appendix 3. Detailed Logs by U.S. Geological Survey Personnel of Sediments Penetrated by Test Holes in the Susquehanna River Valley Fill, Southwestern Broome County, New York

Appendix 4. Physical and Chemical Properties of Water Samples from the Susquehanna River Valley-Fill Aquifer System, and from the Susquehanna River Near Endicott, New York 


\section{Appendix 3. Detailed Logs of Sediments Penetrated by Test Holes in the Susquehanna River Valley Fill, Southwestern Broome County, New York}

The following abbreviations are used in this appendix: $\mathrm{ft}$, feet; mm, millimeters; gal, gallons; min, minutes; <, less than. Sediment grain size: c., coarse; m., medium; f., fine; vc., very coarse; vf., very fine. $5 \mathrm{Y} 5 / 2$, N4, and similar terms: colors from Munsell soil color charts (Munsell, 1975).

\section{BM 476-Auger Hole Near Tri Cities Airport, October 1980}

0 to 15 feet.- Silt, some clayey silt, oxidized (top) becoming less oxidized with depth

15 to 32 feet. - Gravel, ranging from dense gray (5Y5/1) gravel clogged with silt to loose sandy gravel with trace silt 32 to 57 feet. - Silt, fine, unoxidized, massive; possibly interbedded with clay or vf. sand (few samples)

57 to 66 feet.- Till, at least in part, angular shale fragments in a clayey silt matrix, dense; may contain some gravel clogged with silt, also some very coarse sand

66 feet.-Refusal, possibly bedrock

\section{BM 484-Auger Hole in Gravel Pit Near Tri- Cities Airport, October 1980}

\section{Pit Wall (Land Surface 830 Feet Altitude)}

0 to 10 feet.-Pebble gravel, clean, very bright; no soil profile, possibly regraded surface

10 to 20 feet.-Sand, $m$. to vf. sand, a few layers of f. pebble gravel, apparent dips horizontal or to the west, some ripples observed along contact

\section{Auger Hole on Pit Floor (810 Feet Altitude)}

0 to 27 feet. - Sand, $m$. to $f$. and f. to vf.; also fine pebble gravel or pebbly f. to c. sand, trace silt, bright, 10 YR $5 / 2$ in layers about 1 foot thick at $1,7,10,16,21$, possibly 22 to 26(?), and 26 feet; water table no deeper than 11 feet 27 to 57 feet. - Sand, vf. clean; thick layers of silt and silty vf. sand; mainly 2.5 to 5 Y $5 / 2$

57 to 82.5 feet.- Silt, $5 Y 4 / 1$; with numerous thin layers or partings of clay, reddish gray $10 \mathrm{R} 5 / 1$ to light olive gray $5 \mathrm{Y} 6 / 2$; also layered silty vf. sand and (at 68 feet) a little $\mathrm{m}$. to f. sand

82.5 to 84 feet.-Boulder(s) of siltstone and shale 84 to 85 feet.- Sand, f. to c., a little silt, black, weakly calcareous

85 to 88 feet.- Gravel, mostly granules and f. pebbles, clogged with silt, firm

\section{BM 466-Test Well at Mercereau Park, December 1980}

0 to 15 feet.- Silt, a little clay, brown

15 to 22 feet.- Silt, a little vf. sand, brown, noncalcareous

22 to 22.5 feet.-Gravel and f. sand, water-yielding

22.5 to 37 feet.- Sand, vf. to f., some silt, oxidized 10YR 4/3, highly calcareous, layers of silt and rare pebbles

37 to 42 feet.- Silt and vf. sand, highly calcareous; gray, layers of clay, weak red $2.5 \mathrm{YR} 5 / 2$

42 to 47 feet.-Clay, weak red, perhaps interbedded with silt

47 to 53 feet.- Sand, vf., gray N4, highly calcareous, and silt

53 to 58 feet. - Sand, f. to vf., a little c. to vc. sand, and a few pebbles up to 2 inches in diameter. Small probably organic fragments, apparently flattened plant stems, in cuttings, from 57 feet

58 to 60 feet.- Sand, vf. to vc., some pebbles, gray, water yielding. Pebble count (PC) at 58 feet: 110 local/1 limestone/ 6 other. Some pebbles have surficial calcareous films 60 to 66 feet.- -Sand, f. to vc., loose, clean, slight trace of brown silt, sand is dark olive gray 5 Y $3 / 1$ and nearly all local shale but weakly calcareous due to a few limestone grains, water-yielding

66 to 72 feet.-Gravel, small pebbles to granules, and $\mathrm{m}$. to vc. sand, clean, slight trace of brown silt, loose. PC at 67 feet 112 local $/ 3$ limestone/8 other

72 to 98 feet. - Gravel, granules and a few small pebbles, and vc. sand, grading downward to c. pebble gravel and $\mathrm{m}$. to vc. sand, with a little f. sand; generally loose with only a trace of silt, water yielding, oxidized, but a few layers of sand or gravel clogged with silt. Sand is dark gray-brown $2.5 \mathrm{Y}-10 \mathrm{YR}$ $5 / 2$ and nearly all local shale, weakly calcareous

98 to 108 feet.- Sand, m. to vc., some f. sand, a few pebbles, generally oxidized; numerous layers of coarse sand and gravel clogged with silt, some unoxidized; moderately water yielding, shale-grain sand. PC at 100 feet: 32 local/1 limestone/8 other, nearly all are rounded

108 to 115 feet.-Gravel, granules and f. pebbles, some c to vc. sand, clean, water-yielding; perhaps finer grained near base, oxidized. Nearly all grains are shale, moderately calcareous due to scattered limestone. PC at 110 feet: 102 local/7 limestone/16 other

115 to 116 feet.- Sand, m. to c. some f. to vf. and much silt; dense, gray, mostly shale grains, unoxidized

116 to 122 feet. - Sand, m. to vc., a little f. to vf. sand, a few pebbles, variable silty, gray, unoxidized. Layers of sand clogged with silt, apparently interbedded with cleaner sand 122 to 124 feet. - Gravel, c., all shale stones, and sand, f. to $\mathrm{vc}$, in part clogged with silt, water yielding 124 to 126.5 feet.-Bedrock, shale 
Screens installed 109.5 to 114 feet and 115.5 to 120 feet, 0.012 -slot

Bailer tests, in open-ended casing (table 3-1)

Test of final well: Pumped at 5.8 gallons per minute for

1.9 hours, drawdown constant at about 0.15 feet

Table 3-1. Bailer tests.

[ft, feet; gal/min, gallons per minute; min, minutes; —, no measurement]

\begin{tabular}{cccc}
\hline $\begin{array}{c}\text { Casing depth } \\
\text { (ft) }\end{array}$ & $\begin{array}{c}\text { Rate } \\
\text { (gal/min) }\end{array}$ & $\begin{array}{c}\text { Drawdown } \\
\text { (ft) }\end{array}$ & $\begin{array}{c}\text { Time } \\
\text { (min) }\end{array}$ \\
\hline 60 & $10+$ & - & 5 \\
65 & 40 & Negligible & 5 \\
81 & 35 & Negligible & 3 \\
90 & 42 & Negligible & 4 \\
92 & 40 & Negligible & 4 \\
98 & 40 & 15 & 5 \\
100 & 40 & 8 & 5 \\
110 & 40 & Small (through 8-ft gravel plug) & Brief \\
122 & 30 & 10 & 5 \\
\hline
\end{tabular}

\section{BM 775-Test Well EN-D36, June 2004}

Well log, based on field examination of samples and on $\log$ by S. Fisher and E. Stoner (Groundwater Sciences Corporation, written commun., 2004).

0 to 8 feet.-Loam or sandy loam with scattered rounded pebbles, dark brown 7.5 YR 3/3.

8 to 18 feet.-Sand, medium to coarse, highly calcareous, loose, moderately bright but shale grains predominate.

18 to 24 feet.- Sand, medium to fine, highly calcareous, loose, dark yellowish brown 10YR4/4. A few layers of silt at 19 feet

24 to 30 feet.-Gravel (rounded pebbles $<1$ inch diameter), bright, and coarse to fine sand

Pebble count at 25 feet: 8 local/9 limestone/ 8 other Pebble count at 29 feet: 9 local/ 1 limestone/5 other 30 to 34 feet.- Sand, fine to coarse, loose, highly calcareous, pepper and salt texture, 15 percent rounded pebbles 34 to 80 feet.- Silt (mostly coarse silt), olive 5Y5/4 34 to 38 feet, dark gray 5Y4/1 38 to 80 feet; weakly calcareous (chiefly the coarsest fraction); massive to faintly layered; with scattered layers of noncalcareous clay, weak red $2.5 \mathrm{YR} 5 / 2$ to reddish gray $5 \mathrm{YR} 5 / 2$, typically 0.005 to 0.03 foot thick, typically about 1 foot apart. Numerous embedded stones (a few rounded) 79.5 to 80

80 to 112.4 feet. - Till: angular shale stones and fine to very coarse shale-grain sand, in a matrix (estimated 20 percent) of silt and clay; weakly calcareous to noncalcareous, greenish gray 5GY4.5/1 (top) to gray N4 (below 86 feet); dense and compact, many large stones shattered by drill
112.4 to 129 feet.- Shale, massive, occasional calcite veins; highly fractured 112.4 to 115 feet, fracture at 120 feet, and significant loss of drilling water 124 to 129 feet

\section{Interpretation of Lacustrine Sediment 34 to 80 Feet}

Throughout this hole, a split-spoon sampler was driven 2 feet beyond the end of the casing, after which the casing was advanced 2 feet, cleaned out, and the process repeated. Thus, 23 driven cores were obtained within the 46 feet of lacustrine silt and clay penetrated from 34 to 80 -foot depth. Total length of recovered cores was 30.55 feet. Of the 23 cores, 14 contained one layer of pink clay; two cores contained 2 such layers, one contained 3 layers, and 6 contained none. Layers of pink clay were reported by S. Fisher 1 inch or 2 inches below the tops of 3 of these cores, but either were not recognized or were interpreted as disturbed drill cuttings by Randall. These questionable layers were ignored in compiling the foregoing totals, but the following extrapolation process approximately accounts for such layers.

Given that 21 clay layers were recognized in 30.55 feet of core, extrapolation suggests that 32 clay layers would have been recognized if all 46 feet of lacustrine sediment penetrated by this well had been recovered. Layers of pink clay were individually identified by S. Fisher in two nearby cored holes drilled by Groundwater Sciences Corporation in 2004 that completely penetrated the lacustrine sediment. Following the same computational scheme applied to EN-D36, a total of 55 pink clay layers in 52 feet of lacustrine sediment were calculated to be present at EN-D35 (Adams Avenue), and 89 pink clay layers in 65 feet of lacustrine sediment at EN-D37 (McKinley Avenue; see Groundwater Sciences Corporation [2013, plate 1-1] for locations of these test holes)

\section{Significance of Lacustrine Sediment}

Depositional sequences of thin layers of clay separated by generally thicker layers of silt are commonly interpreted as multiple annual pairs (varves); the silt layers were deposited during summers when an abundance of turbid meltwater derived from melting ice upvalley entered the lake; the clay layers were deposited during winters when input of meltwater and suspended sediment ceased and clay suspended in the now-quiet water could gradually settle. Varved lacustrine sediment, capped by bright outwash sand and gravel, is continuous north of the Susquehanna River in Endicott from Patterson Creek in Endwell west to Nanticoke Creek in West Endicott (Randall, 1986; Wolcott and Coon, 2001). The logs of EN-D35, EN-D36, and EN-D37 suggest that during deglaciation an open lake existed near McKinley Avenue for at least 32 years and locally at least 89 years before deltaic and (or) fluvial outwash filled and extinguished the lake. The presence of many subhorizontal layers of nearly impermeable clay within several tens of feet of poorly permeable silt 
renders this lacustrine deposit an imposing barrier to infiltration of recharge and any dissolved contaminants from the surficial outwash aquifer to any deeper aquifers, except in a few localities where the surficial outwash is collapsed to much lower altitude as a result of melting of buried ice blocks after outwash deposition (see Groundwater Sciences Corporation, 2013, plate 2-1).

\section{BM2680 - Test Well Near Tri Cities Airport, September 2013}

0 to 20 feet.- Silt, some very fine to fine sand with rare coarser grains, weakly calcareous (due entirely to a few sand grains), dark yellowish brown 10YR 4/4 (wet) 0 to 10 feet, dark grayish brown 2.5 Y 3-4/2 10 to 20 feet. Plant fibers abundant 0 to 15 feet., absent 15 to 20 feet

20 to 50 feet. - Silt and very fine sand, a little fine sand, traces of medium sand near base, weakly calcareous (20 to 30 feet) to calcareous (30 to 50 feet). Olive gray $5 \mathrm{Y} 4 / 2$ (top) to gray $(5 \mathrm{Y} 4 / 1)$. Nearly all sand grains are single minerals, mostly clear, white, or rusty-stained. A few small dark brown fragments of wood or plant stems in all samples

50 to 90 feet.- - Sand, very fine to fine, traces of silt, gray, calcareous due to a few light-colored carbonate grains (no dark carbonate). A few of the largest sand grains appear to be shale (silvery color, composed of many tiny fragments) but most grains are single minerals. Sand readily heaved into well 90 to 95 feet.- Sand, very fine to medium, a little coarser sand, and fine rounded pebbles all $<8 \mathrm{~mm}$ ( $0.3 \mathrm{inch})$; calcareous, very dark grayish brown 10 YR $4 / 2$. Pebble count 13 local/1 limestone/11 other: [13 local noncalcareous gray shale or very fine sandstone, 1 dark gray limestone, 1 gray chert, 3 metamorphic, 2 quartz, 4 light-colored fine-grained quartzitic sandstone, 1 other.]
95 to 115 feet.- Sand, mostly medium to fine, some coarse sand; about 33 percent of sand grains are shale (all noncalcareous); nearly 50 percent of grains are clear to white, also many brown to gray carbonate grains (no dark blue limestone recognized)

115 to 120 feet. - Sand, mostly medium to fine, some coarse sand, scattered pebbles; shale grains estimated as 40 percent of sand; formation heaves. Pebble count 25/0/8: [19 local shale/ siltstone, olive gray, some weakly calcareous; 6 similar but lighter color; 1 dark calcareous shale; 1 pink quartzite; 1 dark crystalline rock; 5 dark red very fine sandstone]

120 to 127 feet. [no data]

127 to 132 feet. - Sand, fine to medium, gray, with a few small pebbles (10 $\mathrm{mm}$ or smaller, rounded); drilled 5 feet ahead of casing in poorly water-yielding (silty?) sediment. Pebble count at 132 feet 43/2/13: [43 local shale or siltstone, gray, soft, noncalcareous; 2 dark limestone or highly calcareous shale; 12 quartzite or chert (4 dark, 8 light), 1 other]

132 to 135 feet.- Sand, mostly medium to very coarse, calcareous but predominantly shale grains; yields some water, heaved readily

135 to 140 feet.- Gravel and/or medium to very coarse sand, all clogged with silt

Likely 140 to 143 feet.-Possible very clayey c gravel which heaved up the well casing and was eventually removed with difficulty

143 to 145 feet. - Sand, medium to very coarse, predominantly shale grains, calcareous, heaves and yields water abundantly — water level equilibrates at approximately 15 feet from land surface. Driller reports that this zone was pumped 5 hours at 20 gallons per minute (with water flowing up through 12 feet of sand plug in casing), drawdown 8.5 feet. Water cleared, then intermittently became lightly turbid, then cleared again 
For additional information write to:

Director, New York Water Science Center

U.S. Geological Survey

30 Brown Road

Ithaca, NY 14850

Information requests:

(518) 285-5602

or visit our Web site at:

http://ny.water.usgs.gov

Publishing support by:

The Pembroke Publishing Service Center. 
